\title{
The challenges of solar hybrid PVT systems in the food processing industry
}

\author{
María Herrando $^{\mathrm{a}, *}$, Raquel Simón ${ }^{\mathrm{b}}$, Isabel Guedea ${ }^{\mathrm{b}}$, Norberto Fueyo ${ }^{\mathrm{a}}$ \\ ${ }^{a}$ Fluid Mechanics Group, School of Engineering and Architecture, University of Zaragoza, María de Luna 3, 50018 Zaragoza, Spain \\ ${ }^{\mathrm{b}}$ EndeF Engineering S.L., Pol. Ciudad del Transporte, 50820 Zaragoza, Spain
}

\section{A R T I C L E I N F O}

\section{Keywords:}

Absorption chiller

Carbon pricing

Hybrid PVT

Life cycle savings

Payback time

Solar collector

\begin{abstract}
A B S T R A C T
This paper assesses the challenges of alternative solar systems based on hybrid PVT collectors coupled with an absorption chiller $\left(\mathrm{AbCH}\right.$, single-stage $\left.\mathrm{NH}_{3}-\mathrm{H}_{2} \mathrm{O}\right)$ in the food-processing industry, from the technical, economic and environmental points of view. This type of industry is usually characterised by a constant cooling demand throughout the year, hot water demand for production processes and electricity consumption for factory equipment and lighting. To the authors' knowledge, this work constitutes one of the first studies to address the integration of PVT-water collectors with a single-stage $\mathrm{NH}_{3}-\mathrm{H}_{2} \mathrm{O} \mathrm{AbCH}$ for industrial applications. Two alternative PVT-water collectors are analysed, covered and uncovered. A biomass boiler is proposed as an auxiliary heater. To compare the proposed solar solutions, a vegetable and fruit processing and canning factory is considered as a representative case study. Hourly transient simulations considering the real factory demands and real weather data are performed over a year. Two main challenges are found for the solar systems based on the covered PVT collectors, an AbCH and a biomass boiler: the overlapping of the cooling and hot water demands of the food-processing industry, and the high hot water temperatures required. If, alternatively, the current electrical chillers are retained, the system based on uncovered PVT collectors has a reasonable-to-attractive payback time (14.3 years). When the potential environmental benefit is quantified (through carbon pricing), all the proposed solar systems become economically attractive, i.e., with positive total cost savings at the end of the system lifetime. Still, the high cost of PVT collectors, along with the considerably lower price of fuels compared to electricity, hinder the potential of systems that displace fossil fuels.
\end{abstract}

\section{Introduction}

The industry sector accounts for $25 \%$ of the total final energy consumption in the EU [1]. Heating and cooling (H\&C) is the largest energy use in Europe, responsible for $51 \%$ of the total final energy demand (580 Mtoe) $[1,2]$. Buildings are the main consumers of H\&C: $45 \%$ of the energy for H\&C is used in the residential sector, $37 \%$ in industry and $18 \%$ in services [3]. Meanwhile, the renewable energy share for $\mathrm{H} \& \mathrm{C}$ in the EU is still 19\%, although it has almost doubled in the last ten years from $10 \%$ in 2005 [1]. Therefore, even though Europe is on the right track, there is still a long way towards a decarbonised economy. To this end, the European Commission (EC) adopted a H\&C Strategy in February 2016 as part of its wider Energy Union Package, that aims at reducing the EU's energy imports and dependency, cutting costs for households and businesses, and delivering the greenhouse emission reduction levels necessary to meet its commitments under the climate agreement reached at the COP21 climate conference in Paris [3]. According to the EC's H\&C Strategy, further research and innovation are required to support the development of new technologies that can deliver low-carbon and renewable $\mathrm{H} \& \mathrm{C}$, and also improve and enable the exploitation of the full potential of current technologies and solutions.

The food-processing industry is often characterised by a simultaneous demand for hot water and cooling, for cleaning/sterilising and food-conservation respectively, as well as electricity. This industry is the largest manufacturing sector in the EU in terms of both turnover (circa $€ 965 \mathrm{bn}$ ) and the number of active companies (circa 310,000) [4]. Moreover, the bulk of demand occurs during the day, which potentially makes it a good match for solar energy production. Thus, solar heating and cooling (SHC) technologies appear as an interesting option to increase the renewable energy share and thus reduce the dependence on fossil fuels and the associated emissions. Recently, SHC systems have been gaining attention and research efforts [5].

Previous research has mainly focused on the integration of solarthermal collectors [6-8], such as flat plate [9-11], evacuated tube (ETC) $[12,13]$, parabolic through $[14,15]$, or linear Fresnel microconcentrating collectors [16] with cooling technologies, such as

\footnotetext{
* Corresponding author.

E-mail address: mherrando@unizar.es (M. Herrando).
} 


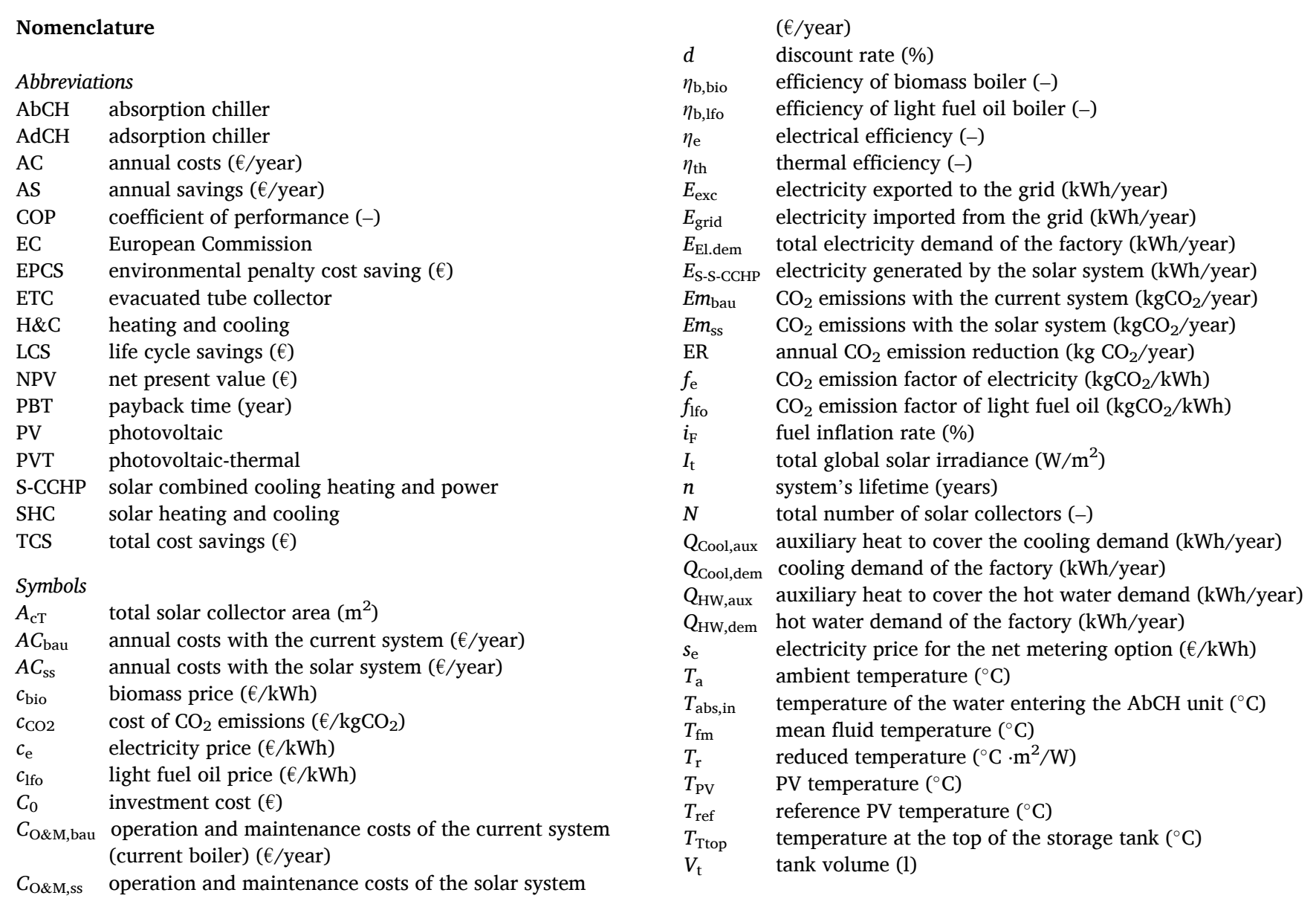

absorption (AbCH) [17] and adsorption chillers (AdCH) [8], for the provision of H\&C $[18,19]$. Some studies have analysed compound parabolic concentrators coupled to single/double effect $\mathrm{LiBr}-\mathrm{H}_{2} \mathrm{O}$ AbCH [20,21], or coupled to AdCH [22]. Alternatively, other authors have considered solar desiccant and evaporative cooling systems [23]. SHC systems based on ETC have attracted attention as ETCs reach the fluid temperatures required to run $\mathrm{AbCH}$ units [24] with somewhat lower costs than other solar technologies [25]. As an alternative, other authors have proposed the integration of PV systems with electrically-driven heat-pump/chiller units to heat or cool depending on the operation mode $[26,27]$.

Less attention has been paid in the literature to the use of hybrid photovoltaic-thermal (PVT) collectors with cooling technologies. PVT systems generate both electricity and a useful thermal output simultaneously from the same aperture area $[28,29]$, achieving a higher overall efficiency than separate PV and solar-thermal collectors [30-32]. Previous research on PVT water systems showed promising results for the provision of electricity and domestic hot water [33], and also space heating [28], in single-family houses, obtaining reasonable-to-attractive payback times in Mediterranean cities. The relevance and potential of PVT collectors and their integration with other components to obtain new solutions in HVAC systems are underpinned by the creation of a new Task 60 of PVT systems in the SHC Programme of the International Energy Agency (IEA) [34].

The combined generation makes PVT collectors an interesting solution in combination with solar-driven cooling technologies for heating, cooling and power provision, supporting the rapidly growing cooling sector $[35,36]$. A previous review summarised the current developments in the field of PVT collectors for cooling purposes and identified the opportunity of using PVT for absorption cooling system [18]. Most of the previous research has focused on integrating a refrigerant PVT collector as the evaporator of a solar-assisted heat pump for the heating provision [37-39], or as the condenser in refrigeration mode [40]. Some authors propose to combine concentrated PVT collectors with $\mathrm{LiBr}-\mathrm{H}_{2} \mathrm{O}$ AbCH [41-43], or air PVT systems with an air-source heat pump [44,45]. Other studies have integrated flat-plate PVT water collectors with a water-to-water electrically-driven heat-pump [46,47], with a watersource heat pump $[48,49]$, with an air-source heat pump [50,51] or with an AdCH unit [52]. Recent studies have shown that coefficients of performance (COP) of up to 0.8 can be achieved by solar-driven singlestage $\mathrm{LiBr}-\mathrm{H}_{2} \mathrm{O} \mathrm{AbCH}[11,53]$. In this context, other authors $[35,54,55]$ integrated PVT water collectors with an $\mathrm{AbCH}$ and concluded that this combination has an important potential for energy savings, as the combination of PVT and cooling technologies maximises the use of the PVT thermal output, particularly in summer. Previous research has integrated these systems mainly in residential buildings [36,56], fitness centres and offices [5,47,57,58], universities [35,54], or hotels [59] while less attention has been paid to the industry sector. For instance, previous authors analysed both glazed and unglazed PVT collectors with coupled half and single-effect $\mathrm{LiBr}-\mathrm{H}_{2} \mathrm{O} \mathrm{AbCH}$, for domestic hot water, cooling and electricity provision in a typical high-rise hotel building located in the subtropical city, obtaining reasonable payback times (12.7 years) [59]. In a previous work by the authors, a payback time of 16.7 years was estimated for a system based on PVT water collectors coupled with single-stage $\mathrm{LiBr}-\mathrm{H}_{2} \mathrm{O} \mathrm{AbCH}$ at a university in southern Italy [35].

A large number of papers have investigated separately the performance of PVT systems (such as in Refs. $[30,60,61]$, among others) or 
SHC systems (such as in Refs. [16,62,63]); analysed the integration of PVT collectors with heat pumps for space heating purposes $[48,50,51,64]$, or their integration with cooling technologies for cooling and power generation [65-67]. However, the integration of PVT collectors as solar combined cooling, heating and power (S-CCHP) systems is scarcer $[43,47]$, and none of the studies found by the present authors addresses the integration of water PVT collectors with a single-stage $\mathrm{NH}_{3}-\mathrm{H}_{2} \mathrm{O}$ AbCH for industrial applications. This work aims to fill this gap, providing an analysis of several solar cooling configurations based on PVT water collectors and comparing them to other widespread solar solutions, applied to a real application in the food processing industry.

Previous works $[35,68]$ highlight the importance of technoeconomic studies to boost PVT technology and the influence of utility prices and public funding in the cost-competitiveness of solar systems [54,69]. Still, previous research focused mainly on system performance (such as in Refs. $[49,51,64]$ ), while economic and environmental analyses are scarcer [68]. Usually, economic and environmental analyses focus on investment cost $[48,70]$, simple payback time $[46,47,56]$, net present value (NPV) [43,71], discounted payback time [33,69,72], and $\mathrm{CO}_{2}$ emission reduction $[28,73]$. This work proposes to go a step forward and combine the system costs and savings (NPV) with potential environmental benefits, through the introduction of carbon pricing, to economically quantify potential $\mathrm{CO}_{2}$ emissions reduction and add it to the life cycle savings (LCS) to obtain the total cost savings (TCS). This allows the comparison of renewable technologies with different energy outputs (thermal and electrical) with a single economic indicator (TCS) [68].

This research aims to investigate the challenges of S-CCHP systems in the food-processing industry, from the technical, economic and environmental points of view. To this end, two alternative PVT collectors are coupled with a commercial AbCH (single-stage $\mathrm{NH}_{3}-\mathrm{H}_{2} \mathrm{O}$ ) via a thermal storage tank, for the combined supply of hot water, cooling and electricity. As an alternative system, an SHC system is also analysed, based on ETCs coupled with the AbCH via a thermal store. Additionally, another solar system based on PVT collectors that generate hot water and directly power the current electrically-driven chillers is assessed. In all the configurations, a biomass boiler is proposed as an auxiliary heater.

The novelty of this work lies not only in the technical systems analysed (PVT collectors and solar absorption (single-stage $\mathrm{NH}_{3}-\mathrm{H}_{2} \mathrm{O}$ ) for electricity, heating and cooling purposes) but also in the approach followed for its application to a high energy-consuming sector such as the food-processing industry, which has not been yet assessed in the literature to the best of the authors' knowledge. This sector has an important potential for solar energy use, as pointed out in Refs. [74-76]. Besides, this work undertakes a comprehensive analysis of the proposed systems, including the integration of the economic and environmental benefits of the proposed systems by economically quantifying $\mathrm{CO}_{2}$ emissions reduction, to overall evaluate the total potential of the proposed solutions and compare them with other widespread solar solutions.

\section{Methodology}

In this work, five alternative solar systems have been modelled in TRNSYS [77], and hourly transient simulations considering real weather data [78] are conducted over a year. The real energy consumptions of a representative food-processing factory are used as a case study to analyse and compare the different solar alternatives. The existing arrangements for electricity and hot water supply are used as a baseline to estimate the energy and cost savings of the proposed solar systems. For the economic analysis, the current utility prices and the operation and maintenance costs (O\&M) are considered to estimate the annual savings, which are used along with the system's investment cost to estimate the system's discounted payback time (PBT) and the net present value $(N P V)$. The potential $\mathrm{CO}_{2}$ emissions reduction $(E R)$ is also evaluated and used to estimate the total environmental penalty cost saving (EPCS) and the total cost savings (TCS) of each of the proposed solar systems.

\subsection{Energy demand in the food-processing industry}

Food-processing industries with high energy consumption levels include pig slaughterhouse, beer brewery and vegetable and fruit processing and canning [79]. In general, industries in this class are characterised by cooling, hot water and electricity demands spread throughout the year. As shown in Table 1, pig slaughterhouse and food processing and canning have a constant cooling demand throughout the year for food conservation and hot water demand for cleaning/sterilising and production processes on working days. Beer breweries usually have simultaneous cooling and hot water demands on working hours for the beer production processes. In the aforementioned industries, required temperatures for cooling and hot water are similar, with some of them (e.g. vegetable and fruit processing and canning) demanding higher temperatures for food cooking. All of them usually have a baseload electricity consumption for ancillary equipment, and a larger consumption on working days due to factory equipment and lighting.

One of the challenges for energy provision in this type of industries is the simultaneous demand for cooling, hot water and electricity. These demands are larger during working hours, which usually occur during the day when solar irradiance is also higher. Therefore, the present work analyses alternative solar solutions capable of simultaneously generating hot water, cooling and electricity.

From the food-processing industries detailed in Table 1, vegetable and fruit processing and canning is selected as a representative case study to analyse and compare the proposed solar solutions. We choose this industry because it is considerably demanding in terms of both temperature requirements and constant provision. It is also believed that the conclusions can be extrapolated to other food-processing industries.

The selected food-processing factory is located in Zaragoza (Spain), which has a semi-arid Mediterranean climate. The factory uses an average of $650 \mathrm{~kg} / \mathrm{h}$ of hot water per day, 150 days per year, constant from 9:00 to 17:00 ( $8 \mathrm{~h}$ total), Monday to Friday. Currently, there is no tank for hot water storage, so the hot water demand is satisfied instantaneously by a flue firetube boiler (NCK 150.8 of SOGECAL) that uses light fuel oil to heat water mains from around $13^{\circ} \mathrm{C}$ to $100{ }^{\circ} \mathrm{C}$. The real average boiler efficiency is very low $\left(\eta_{\mathrm{lfo}, \mathrm{b}} \approx 0.47\right)$ due to its need for a high generation rate, along with the fact that it is currently used at very low loads [80]. Table 2 shows the annual hot water demand, estimated considering the hot water consumption and its required temperature increase $\left(\Delta T=100-13^{\circ} \mathrm{C}\right)$. The associated thermal energy consumption is estimated considering the real average boiler efficiency.

The annual electricity consumption for the factory equipment, lighting and other electrical devices is $26,057 \mathrm{kWh} /$ year. This consumption is made up of a continuous, baseload electricity consumption of ancillary equipment ( $24 \mathrm{~h} /$ day, 365 days/year) and larger electricity consumption on working days. It is estimated that the baseload electricity consumption accounts for around $40 \%$ of the total annual consumption, uniformly distributed throughout the year. On working days, this baseload consumption is about $15 \%$ of the total electricity consumption. For the additional working-day load, a flat profile is assumed between 9:00 $\mathrm{h}$ and 17:00 h from Monday to Friday.

The cooling demand is from a production room that requires a constant temperature of $12-15^{\circ} \mathrm{C}$, and from several refrigeration chambers maintained at $0-4{ }^{\circ} \mathrm{C}$. Currently, this demand is satisfied by electrical chillers. The cooling demand is estimated from the current electricity consumption for cooling $(134,000 \mathrm{kWh} /$ year $)$ and the average COP of the current electrical chillers ( $\mathrm{COP}=2.37$ ) (data supplied by the company). The annual cooling demand is distributed uniformly throughout the year ( $24 \mathrm{~h} /$ day, 365 days/year), considering a refrigeration cycle of one hour, as this is also the time step for the transient simulations. In all the proposed solar systems, the cooling needs of the production room are satisfied by the current electrical chillers, thus requiring $38,180 \mathrm{kWh}$ of annual electricity consumption (see Table 2). 
Table 1

Typical energy demand profiles three typical food-processing industries.

\begin{tabular}{|c|c|c|c|c|c|}
\hline \multirow[t]{2}{*}{ Industry } & \multicolumn{2}{|l|}{ Cooling Demand } & \multicolumn{2}{|c|}{ Process hot water } & \multirow[t]{2}{*}{ Electricity } \\
\hline & Profile & Temperature & Profile & Temperature & \\
\hline $\begin{array}{l}\text { Vegetable and fruit processing and } \\
\text { canning }\end{array}$ & $\begin{array}{l}24 \mathrm{~h} / \text { day, } 365 \text { days/ } \\
\text { year }\end{array}$ & $-5 / 0{ }^{\circ} \mathrm{C}$ & $\begin{array}{l}\text { Working } \\
\text { days }\end{array}$ & $100{ }^{\circ} \mathrm{C}$ & \\
\hline Pig slaughterhouse & $\begin{array}{l}24 \mathrm{~h} / \text { day, } 365 \text { days/ } \\
\text { year }\end{array}$ & $-5 / 0{ }^{\circ} \mathrm{C}$ & $\begin{array}{l}\text { Working } \\
\text { days }\end{array}$ & $60^{\circ} \mathrm{C} / 90^{\circ} \mathrm{C}$ & $\begin{array}{l}\text { Baseload ( } 24 \text { h/day, } 365 \text { days/year) + larger in working } \\
\text { days }\end{array}$ \\
\hline Beer brewery & Working days & $-5 / 0{ }^{\circ} \mathrm{C}$ & $\begin{array}{l}\text { Working } \\
\text { days }\end{array}$ & $80^{\circ} \mathrm{C}$ & \\
\hline
\end{tabular}

Table 2

Annual hot water, electricity and cooling demands and their corresponding energy consumptions for the food-processing factory under study.

\begin{tabular}{|c|c|c|}
\hline & $\begin{array}{l}\text { Energy consumption } \\
\text { (kWh/year) }\end{array}$ & $\begin{array}{l}\text { Energy demand } \\
\text { (kWh/year) }\end{array}$ \\
\hline Hot water & 21,949 & 10,316 \\
\hline $\begin{array}{l}\text { Electricity for factory } \\
\text { equipment }\end{array}$ & 26,057 & 26,057 \\
\hline Cooling & 134,000 & 317,185 \\
\hline $\begin{array}{l}\text { - Production room (12-15 } \\
\left.{ }^{\circ} \mathrm{C}\right)\end{array}$ & 38,180 & 90,374 \\
\hline $\begin{array}{l}\text { - Refrigeration chambers } \\
\left(0-4{ }^{\circ} \mathrm{C}\right)\end{array}$ & 95,820 & 226,811 \\
\hline
\end{tabular}

\subsection{PVT collectors integrated with an absorption chiller}

In the proposed S-CCHP systems, the thermal output of the PVT collectors heats the water in a storage tank, which is used to satisfy the hot water demand and to supply the $\mathrm{AbCH}$ (single-stage $\mathrm{NH}_{3}-\mathrm{H}_{2} \mathrm{O}$ ) which then provides the cooling demand. An auxiliary heater is required to reach the delivery temperatures of hot water for food-processing (100 ${ }^{\circ} \mathrm{C}$ ) and to feed the $\mathrm{AbCH}\left(80{ }^{\circ} \mathrm{C}\right)$ (see Fig. 1). To increase the boiler efficiency and decrease the associated $\mathrm{CO}_{2}$ emissions, the current flue firetube boiler is replaced by a biomass boiler to act as an auxiliary heater. The electrical output of PVT collectors is used to satisfy the factory electricity consumption (including the electricity consumption of the production room). In all the proposed configurations, the solar collectors are tilted at $30^{\circ}$.

\subsubsection{PVT collectors}

Two alternative commercial PVT collectors are proposed: a covered PVT collector with a sheet-and-tube absorber made of copper $\left(265 \mathrm{~W}_{\mathrm{p}}\right.$, $1.61 \mathrm{~m}^{2}$ aperture area) and an uncovered PVT collector with a roll-bond absorber made of aluminium ( $300 \mathrm{~W}_{\mathrm{p}}, 1.63 \mathrm{~m}^{2}$ aperture area) [81]. PVT collectors are thermally connected in parallel so that flow rate and inlet and outlet water temperatures are the same in all of them. A constant flow rate of $50 \mathrm{l} / \mathrm{h}$ is used in both PVT collectors [28]. Type 560 and Type 50d in TRNSYS are modified and adjusted to match the thermal efficiency $\left(\eta_{\mathrm{th}}\right)$ and the electrical efficiency $\left(\eta_{\mathrm{e}}\right)$ curves of both PVT collectors respectively (see Fig. 2) [81]:

Covered PVT : $\quad \eta_{\text {th }}=0.51-4.93 \cdot T_{\mathrm{r}}-0.021 \cdot I_{\mathrm{t}} \cdot T_{\mathrm{r}}^{2}$

Uncovered PVT: $\quad \eta_{\text {th }}=0.472-9.5 \cdot T_{\mathrm{r}}$

$T_{\mathrm{r}}=\frac{T_{\mathrm{fm}}-T_{\mathrm{a}}}{I_{\mathrm{t}}}$

Covered PVT: $\quad \eta_{\mathrm{e}}=0.1598 \cdot\left(1-0.0047 \cdot\left(T_{\mathrm{PV}}-T_{\text {ref }}\right)\right)$

Uncovered PVT : $\quad \eta_{\mathrm{e}}=0.1844 \cdot\left(1-0.0039 \cdot\left(T_{\mathrm{PV}}-T_{\mathrm{ref}}\right)\right)$

where $T_{\mathrm{r}}$ is the reduced temperature, $I_{\mathrm{t}}\left(\mathrm{W} / \mathrm{m}^{2}\right)$ is the total global solar irradiance on the surface at a tilted angle, $T_{\mathrm{fm}}$ is the mean fluid temperature, $T_{\mathrm{a}}$ is the ambient temperature, $T_{\mathrm{PV}}$ is the PV cell temperature and $T_{\text {ref }}$ is $25^{\circ} \mathrm{C}$ (as given by the manufacturer).

As shown in Fig. 2 , the thermal $\left(\eta_{\text {th }}\right)$ and electrical $\left(\eta_{\mathrm{e}}\right)$ efficiencies of the covered PVT collector (left) obtained in the simulation (sim) are within $2 \%$ (see error bars) of the respective efficiencies provided by the manufacturer (exp) [81]. In the case of the uncovered PVT collector (right), the electrical efficiency curve obtained in the simulation (sim) is also within $2 \%$ of the respective efficiency provided by the manufacturer (exp) [81], while the thermal efficiency is within 5\%, except for $T_{\mathrm{r}}>$ 0.045 . However these high $T_{\mathrm{r}}$ values are for $T_{\mathrm{in}}>70^{\circ} \mathrm{C}$; and uncovered PVT collectors are not usually operated at temperatures higher than $70{ }^{\circ} \mathrm{C}$, as thermal losses at these temperatures are larger than thermal gains, and therefore water is cooled, rather than heated, in the collector.

\subsubsection{Stratified water storage tank}

The tank is modelled using a stratified water storage tank of constant fluid mass (Type 534 in TRNSYS), considering six fully mixed equalvolume segments that divide the cylinder along its vertical axis. Preheated water for hot water demand is supplied via a port at the top of the

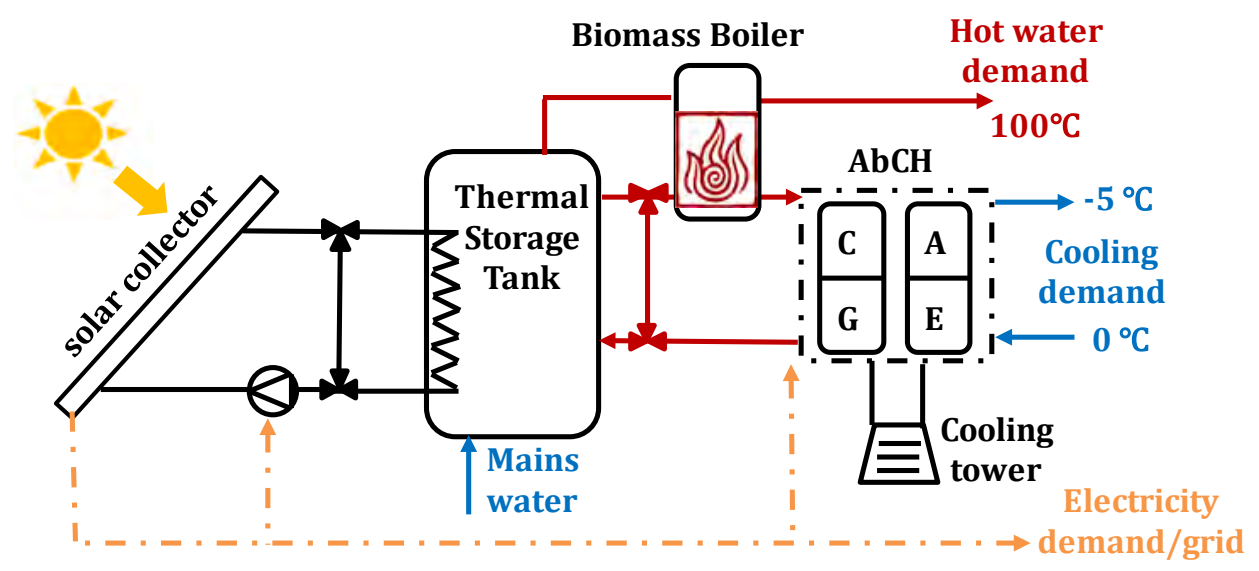

Fig. 1. Schematic of the S-CCHP system based on solar collectors integrated with a single-effect $\mathrm{NH}_{3}-\mathrm{H}_{2} \mathrm{O}$ AbCH unit through a thermal store. 

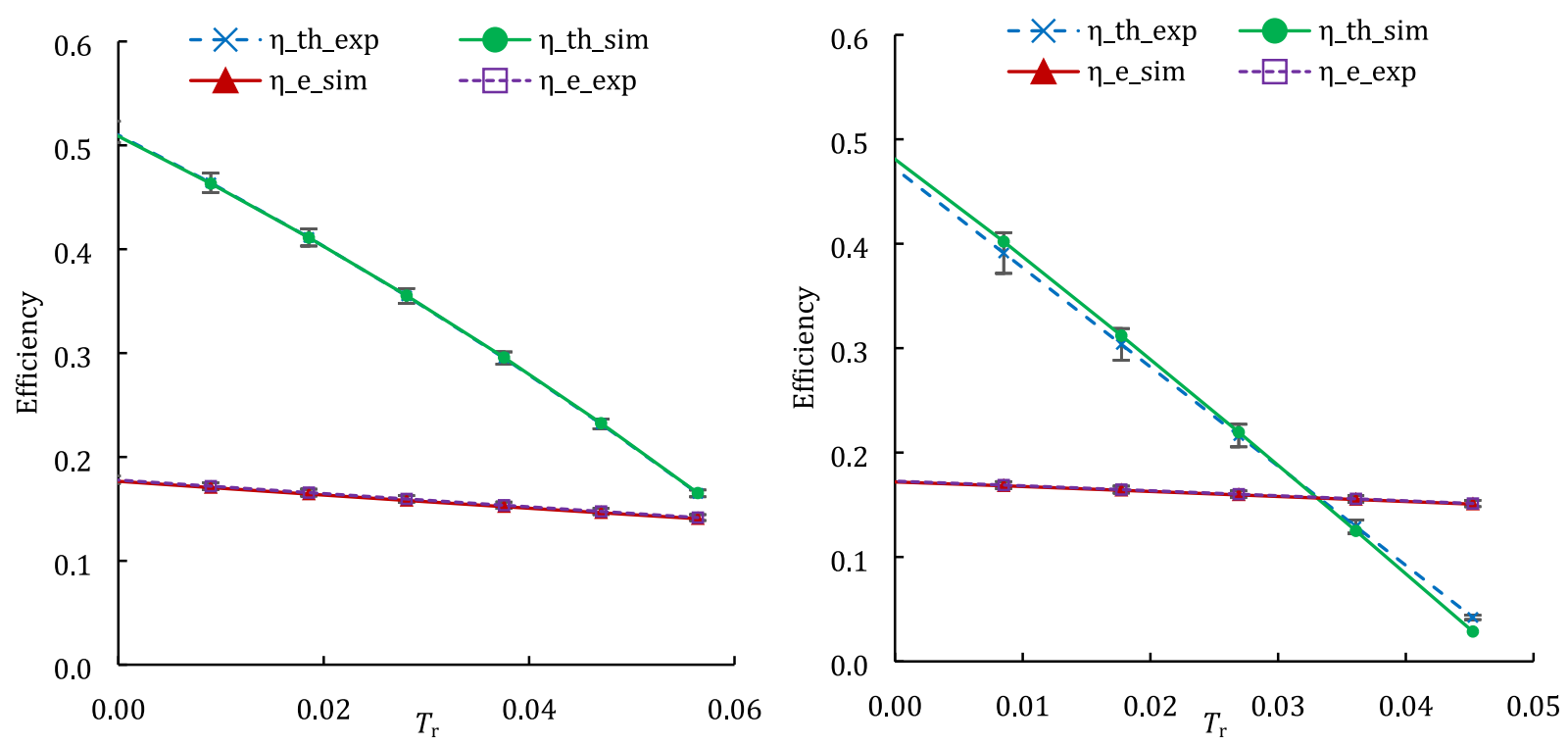

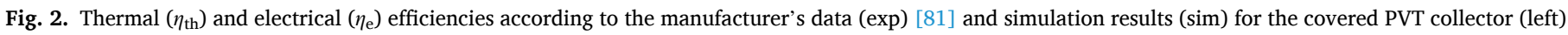
and uncovered PVT collector (right).

tank and water is refilled from the bottom node using utility water. An immersed heat exchanger connected to the PVT collector array runs from the top to the bottom of the tank to heat the water inside the tank. To satisfy the cooling demand, the $\mathrm{AbCH}$ is connected to a second port leaving the tank at the top and entering at the bottom. The storage tank volume varies proportionally with the number of PVT collectors to keep the $V_{\mathrm{t}} / A_{\mathrm{cT}}$ ratio constant, where $V_{\mathrm{t}}$ is the tank volume (litres) and $A_{\mathrm{cT}}$ is the total solar collector area $\left(\mathrm{m}^{2}\right)$. This ratio can be modified and optimised in each solar solution, as detailed in Section 3. The diameter and height of the tank vary according to the tank volume, following a correlation obtained from a set of commercial tanks [82]. The size of the solar immersed heat exchanger coil also varies with the tank size through the variation of the tank height.

\subsubsection{Absorption chiller}

A commercial AbCH (ago-congelo) [83] is selected (nominal cooling capacity of $50 \mathrm{~kW}$ ), which generates chilled fluid at $-5{ }^{\circ} \mathrm{C}$ to provide cooling to the refrigeration chambers. The $\mathrm{AbCH}$ is connected to the top of the storage tank through the proposed biomass boiler to ensure that the water enters the $\mathrm{AbCH}$ at least at $80^{\circ} \mathrm{C}$ (the minimum temperature to start the cycle). Type 107 in TRNSYS is used to model the $\mathrm{AbCH}$, and the data files are modified to fit the performance data provided by the $\mathrm{AbCH}$ manufacturer.

\subsubsection{Biomass boiler}

The peak power of the auxiliary heating is estimated considering the thermal peak power required to meet the hot water demand $(8.2 \mathrm{~kW})$ and the peak power required to drive the $\mathrm{AbCH}(76.1 \mathrm{~kW})$. Therefore, an auxiliary boiler of around $85 \mathrm{~kW}$ is needed to ensure that both the hot water and cooling demands can be satisfied simultaneously in the absence of solar energy output (conservative scenario). From the biomass boilers available in the market, the FIREMATIC model of HERZ is selected, available with peak powers of $80 \mathrm{~kW}$ and $100 \mathrm{~kW}\left(\eta_{\mathrm{b} \text {,bio }} \approx\right.$ 0.93) [84]. This boiler uses pellets as fuel, although it can also be fed with wood chips and other biomass fuels.

\subsection{PVT collectors integrated with electrical chillers}

As an alternative system, the AbCH of Fig. 1 is removed, and all the cooling demand is satisfied with the current electrical chillers fed with the PVT electrical output. The thermal output of the PVT collectors is used to satisfy the hot water demand via the storage tank and the auxiliary biomass boiler, while the electrical output of the PVT collectors matches the factory's electricity consumption as well as the electricity required to satisfy all the cooling demand. The PVT collectors are also tilted at $30^{\circ}$.

\subsection{Evacuated tube collectors integrated with an absorption chiller}

An SHC system based on direct-flow ETCs is also assessed. In this case, the solar collectors of Fig. 1 are ETCs, and there is no electricity generation. The same $\mathrm{AbCH}$, biomass boiler and stratified water storage tank as for the S-CCHP system (Section 2.2) are used. For the ETCs, the commercially available Thermomax DF400 is selected [85], as it has higher optical efficiency and lower heat loss coefficients than the proposed PVT collectors (see Eq. (6)). The selected ETC has an absorber area of $2 \mathrm{~m}^{2}$, an aperture area of $2.16 \mathrm{~m}^{2}$ and the nominal flow rate is used $(120 \mathrm{l} / \mathrm{h})$. The ETCs are also tilted at $30^{\circ}$. The performance data of the ETC provided by the manufacturer is implemented in Type 71 in TRNSYS, modifying and adjusting the parameters to match the thermal efficiency $\left(\eta_{\mathrm{th}}\right)$ :

$\eta_{\text {th }}=0.768-1.36 \cdot T_{\mathrm{r}}-0.053 \cdot I_{\mathrm{t}} \cdot T_{\mathrm{r}}^{2}$

As shown in Fig. 3 , the thermal $\left(\eta_{\text {th }}\right)$ efficiency of the ETC obtained in the simulation (sim) is within $2 \%$ (see error bars) of the respective efficiencies provided by the manufacturer (exp) [85].

\subsection{Economic and environmental analysis}

The PVT collector price is provided by the manufacturer [81], the biomass boiler price is from the manufacturer's web site [84], and the rest of solar system investment costs $\left(C_{0}\right)$ are estimated from price lists available from solar retailers in the EU [86-88]. The cost of the storage tank is estimated using a correlation based on market prices of existing tanks across a range of storage volumes [69]. The total installation costs are also considered [35]. For the solar system based on covered PVT collectors and an $\mathrm{AbCH}$, the main costs are associated with the PVT collectors (41\%), the hydraulic components and storage tank [82] (14\%), the biomass boiler (14\%) and the AbCH (11\%) [5] (see Fig. 4 left). For the system based on PVT collectors and electrical chillers, the covered PVT collector is $53 \%$ of the total cost, and the cost of the uncovered PVT collectors is $47 \%$ of the total (as uncovered collectors are 


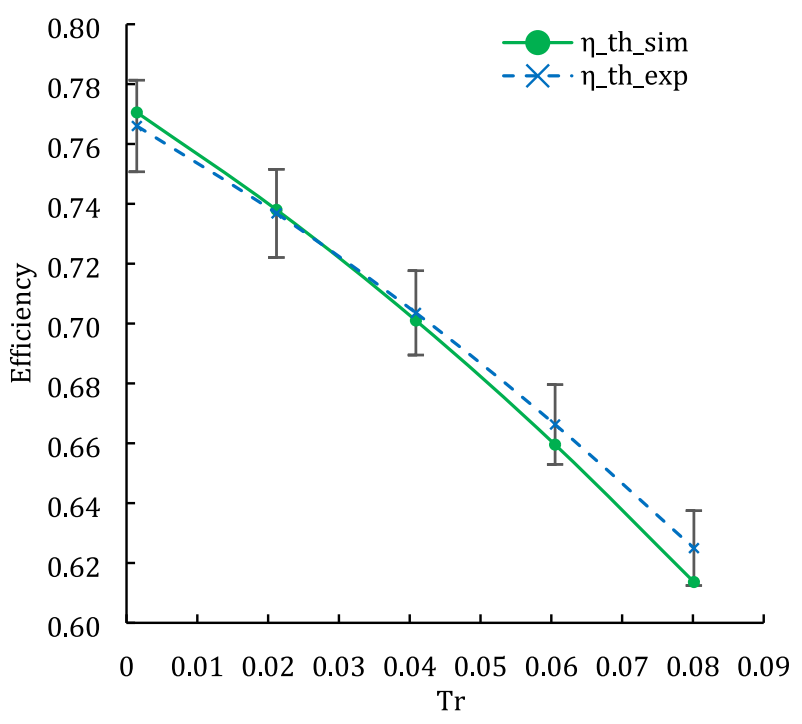

Fig. 3. Thermal ( $\left.\eta_{\text {th }}\right)$ efficiency according to the manufacturer's data (exp) and simulation results (sim) for the ETC.

cheaper than covered ones). In the SHC system, the ETC cost is $25 \%$, the biomass boiler is $18 \%$, and the $\mathrm{AbCH}$ is $13 \%$ (see Fig. 4 right).

To compare the different alternatives, the system discounted payback time $(P B T)$, defined as the period of time required to recover the investment cost $[69,89]$, is estimated:

$P B T=\frac{\ln \left[\frac{C_{0} \cdot\left(i_{F}-d\right)}{A S}+1\right]}{\ln \left(\frac{1+i_{F}}{1+d}\right)}$

where $d$ is the discount rate $(5 \%)[90,91]$ and $i_{\mathrm{F}}$ is the fuel inflation rate (3.5\%) [35]. The annual savings (AS) refer to the difference between the current annual costs that the food-processing factory incurs to cover all the energy demand (e.g. business as usual scenario, $A C_{\text {bau }}$ ), and the annual costs that the factory would incur to cover all the energy demand if the proposed solar system was installed $\left(A C_{\mathrm{ss}}\right)$. In both cases, the associated O\&M costs are included:

$A S=A C_{\text {bau }}-A C_{\mathrm{ss}}$

$A C_{\mathrm{bau}}=E_{\mathrm{El}, \mathrm{dem}} \cdot c_{\mathrm{e}}+\frac{Q_{\mathrm{HW}, \mathrm{dem}}}{\eta_{\mathrm{b}, \mathrm{lfo}}} \cdot c_{\mathrm{lfo}}+C_{\mathrm{O \& M}, \mathrm{bau}}$

$A C_{\mathrm{ss}}=E_{\text {grid }} \cdot c_{\mathrm{e}}+\frac{Q_{\mathrm{HW}, \text { aux }}+Q_{\mathrm{Cool}, \mathrm{aux}}}{\eta_{\mathrm{b}, \mathrm{bio}}} \cdot c_{\text {bio }}+E_{\mathrm{exc}} \cdot s_{\mathrm{e}}+C_{\mathrm{O} \& \mathrm{M}, \mathrm{ss}}$ where $E_{\mathrm{El}, \mathrm{dem}}$ refers to the current total electricity demand of the factory (including the electricity consumed by the electrical chillers, 160,057 $\mathrm{kWh} /$ year), $Q_{\mathrm{HW} \text {,dem }}$ is the hot water demand, $E_{\text {grid }}$ is the electricity demand that cannot be covered by the proposed solar systems and thus should be imported from the grid, $E_{\text {exc }}$ is the electricity excess exported to the grid and imported later on via net metering, $Q_{\mathrm{HW} \text {,aux }}$ and $Q_{\mathrm{Cool}, \mathrm{aux}}$ are the auxiliary heating required to cover the hot water and cooling demands respectively, $c_{\mathrm{e}}$ is the electricity price $(0.152 € / \mathrm{kWh}), s_{\mathrm{e}}$ is electricity price for the net metering option $(0.076 € / \mathrm{kWh}), c_{\mathrm{lfo}}$ is the light fuel oil price $(0.078 € / \mathrm{kWh}), c_{\text {bio }}$ is the biomass (pellets) price $(0.042 € / \mathrm{kWh}), C_{\mathrm{O} \& \mathrm{M}, \text { bau }}$ are the O\&M costs of the current boiler (estimated as $350 € /$ year [92]), and $C_{\mathrm{O} \& \mathrm{M}, \mathrm{ss}}$ are the O\&M costs of the proposed solar systems, estimated as $1 \%$ of the total equipment costs for the PVT-based S-CCHP system and 0.6\% for the ETC-based SHC system [57].

The net present value (NPV) is used to estimate the profitability of the investment. It is defined as the value of all the cash flows over the lifetime ( $n$ ) of an investment discounted to the present value. In this case, it considers the system investment cost and its life cycle savings (LCS), defined as the net present value of the total energy savings over the system lifetime $[33,69,93]$ :

$N P V=L C S-C_{0}=\frac{A S}{d-i_{F}} \cdot\left[1-\left(\frac{1+i_{F}}{1+d}\right)^{n}\right]-C_{0}$

The potential $\mathrm{CO}_{2}$ emission reduction of renewable energies has been one of the main drivers for their increasing appeal and market growth. The annual $\mathrm{CO}_{2}$ emission reduction (ER) of the proposed solar systems is estimated, similarly as with the annual savings, but substituting the utility prices for the $\mathrm{CO}_{2}$ emission factors of light fuel oil and electricity, $f_{\text {lfo }}$ and $f_{\mathrm{e}}$, respectively (the emissions associated with pellets are considered negligible) [94]:

$E R=E m_{\text {bau }}-E m_{s s}$

$E m_{b a u}=E_{E l, d e m} \cdot f_{e}+\frac{Q_{H W, d e m}}{\eta_{l f o, b}} \cdot f_{l f o}$

$E m_{s s}=\left(E_{\text {grid }}-E_{\text {exc }}\right) \cdot f_{e}$

The increasing awareness of climate change has led to the growing momentum for carbon pricing, in an attempt to reduce pollutant emissions and shift towards cleaner technologies. Currently, 51 countries or regions around the world have implemented or have scheduled the implementation of carbon pricing initiatives, involving emission trading systems and carbon taxes [95]. In this line, the total environmental penalty cost saving (EPCS) over the proposed solar systems' lifetime is estimated [68] as:

$E P C S=\frac{E R \cdot c_{C O 2}}{d-i_{F}} \cdot\left[1-\left(\frac{1+i_{F}}{1+d}\right)^{n}\right]$
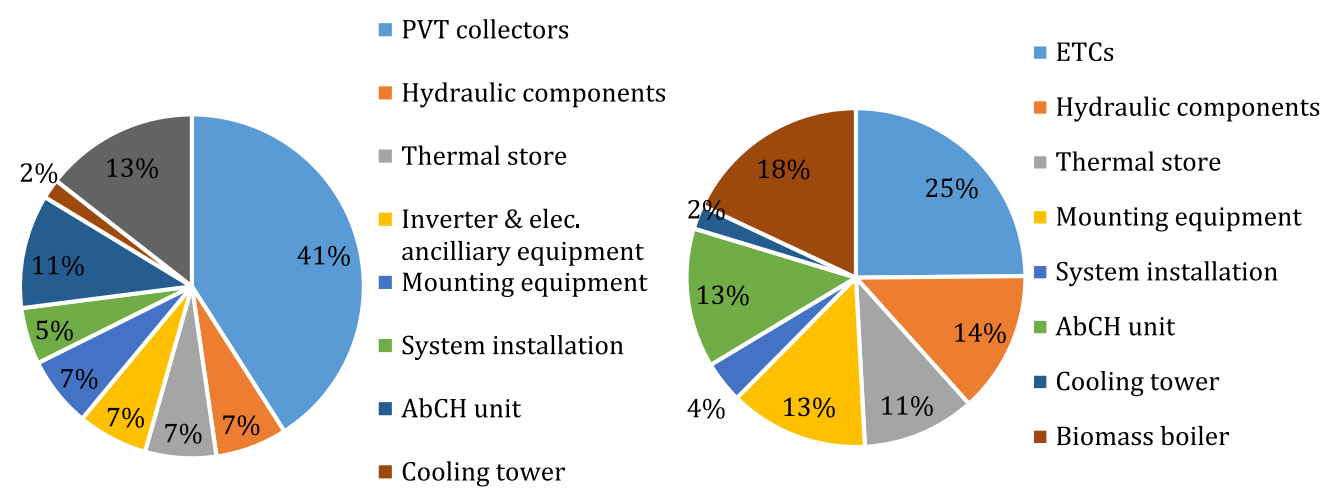

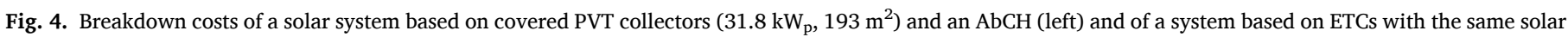
installed area and an $\mathrm{AbCH}$ (right). 
where $c_{\mathrm{CO} 2}$ is the cost of $\mathrm{CO}_{2}$ emissions, which varies with the country/ region. For this analysis, two alternative carbon taxes are considered, the current carbon tax in Spain $\left(0.023 € / \mathrm{kgCO}_{2}\right)$, although currently it only applies to fluorinated gases, and the average value of the carbon taxes in Europe $\left(0.07 € / \mathrm{kgCO}_{2}\right)$ [95].

Finally, the overall economic and environmental potential of the proposed solar systems is estimated through the total cost savings (TCS), as in [68]:

$T C S=N P V+E P C S$

\section{Results and discussion}

The first system analysed is the S-CCHP system based on covered PVT collectors coupled with an AbCH (Fig. 1). A parametric analysis is undertaken to select the optimum system size for the application. The objective is to minimise the system payback time (PBT). It is assumed that the electricity not instantaneously consumed can be fed into the grid and imported later with the net metering option. Once the system size is selected, this system is compared in terms of performance, economics and environmental benefits with the other solar alternatives with the same peak electrical power (in the case of PVT-based systems) or with the same solar field area (in the case of the ETC-based system).

\subsection{Parametric analysis to select the solar system size}

The number of covered PVT collectors $(N)$ is varied from $20\left(32 \mathrm{~m}^{2}\right)$ to $240\left(386 \mathrm{~m}^{2}\right)$, which is the maximum number of PVT collectors that can be installed in the available roof area. Fig. 5 shows that the hot water demand covered increases slowly with the number of PVT collectors, particularly for $N>60$, while the cooling demand covered by PVT thermal output that feeds the $\mathrm{AbCH}$ increases linearly with $N$. The left axis depicts the total electricity demand covered, both instantaneously (i.e. at the time of the PVT generation) and with the net-metering option, that is, by exporting the generation excess and importing it when generation is lower than demand at a later time at the net-metering price $\left(s_{\mathrm{e}}\right)$. It is observed that with around 150 PVT collectors the total electricity that can be instantaneously covered tends to an asymptote (blue squares), while the electricity fed into the grid (red crosses) keeps increasing. This considerably influences the system payback time, as shown in Fig. 6, as the economic savings achieved for this electricity exported and then imported are half of the savings achieved when the electricity is directly used in the factory (because $s_{\mathrm{e}}=c_{\mathrm{e}} / 2$ ). Consequently, the minimum $P B T$ is reached for the S-CCHP system with 120 PVT collectors ( $\left.31.8 \mathrm{~kW}_{\mathrm{p}}, 193 \mathrm{~m}^{2}\right)$.

Meanwhile, the $\mathrm{CO}_{2}$ emission reduction increases linearly with $\mathrm{N}$ (see green triangles in Fig. 6) until $N=220\left(58.3 \mathrm{~kW}_{\mathrm{p}}, 354 \mathrm{~m}^{2}\right)$, when it

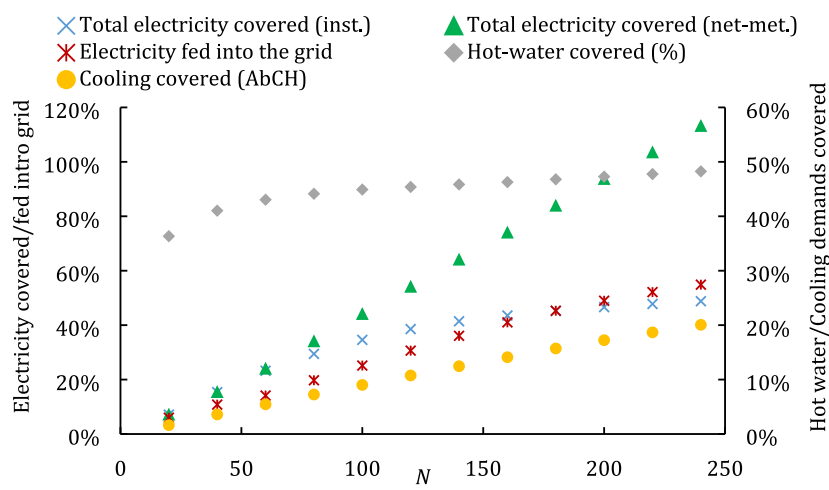

Fig. 5. Total electricity instantaneously covered and with net metering option, electricity fed into the grid, hot water demand covered and cooling demand covered by the PVT thermal output that feeds the $\mathrm{AbCH}$, as a function of the number of PVT collectors $(N)$.

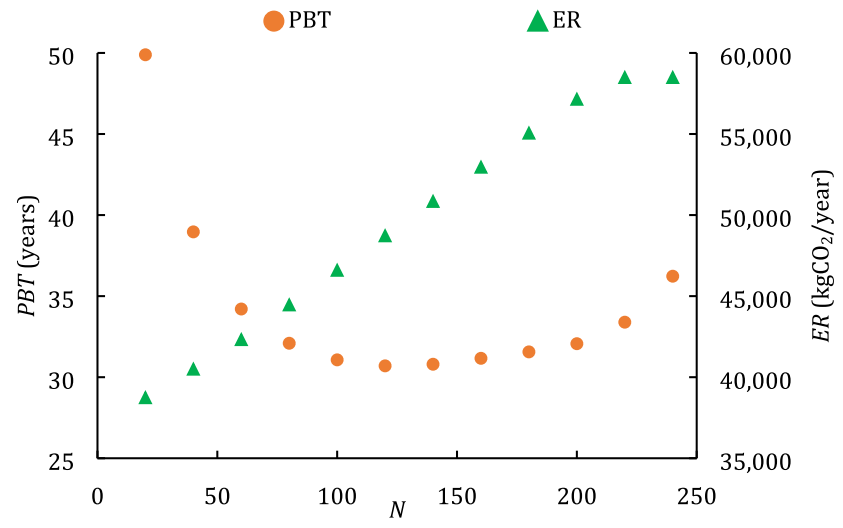

Fig. 6. Payback time $(P B T)$ and $\mathrm{CO}_{2}$ emission reduction (ER) of the covered PVT collectors integrated with the $\mathrm{AbCH}$, as a function of the number of PVT collectors $(N)$.

reaches a maximum, $58,483 \mathrm{~kg}_{\mathrm{CO} 2} /$ year, which is the total $\mathrm{CO}_{2}$ emissions of the current conventional system and thus the maximum emissions that can be reduced. That is, with an S-CCHP system of $58.3 \mathrm{~kW}_{\mathrm{p}}$, all the energy demands of the factory are covered: the electricity demand is satisfied with the PVT electrical output and the hot water and cooling demands are partially covered by the PVT thermal output and the rest by the biomass boiler.

The following sub-sections show transient results of the S-CCHP system $\left(31.8 \mathrm{~kW}_{\mathrm{p}}\right)$ based on the covered PVT collectors, an AbCH and a biomass boiler (Section 3.2.1); the S-CCHP system based on the covered PVT collectors, a biomass boiler and the current electrical chillers (Section 3.2.2); and the SHC system based on ETCs, an AbCH and a biomass boiler (Section 3.2.3). Section 3.3 presents the annual performance, economic and environmental assessments and comparison of the proposed solar systems. Finally, Section 3.4 includes a sensitivity analysis to assess the influence of the investment cost and utility prices on the cost-competitiveness of the system.

\subsection{Transient results}

\subsubsection{Covered PVT collectors integrated with an absorption chiller}

This section presents the transient results on an hourly basis for the $S$ CCHP system $\left(31.8 \mathrm{~kW}_{\mathrm{p}}, 193 \mathrm{~m}^{2}\right)$ shown in Fig. 1 and selected in the previous section. Based on previous studies $[28,54]$ and preliminary analyses, the selected ratio of storage tank volume to solar collector area is $V_{\mathrm{t}} / A_{\mathrm{cT}}=50 \mathrm{l} / \mathrm{m}^{2}$ and a constant PVT collector flow-rate of $50 \mathrm{l} / \mathrm{h}$ is maintained [35]. Nine representative days from Saturday to the following Sunday are selected to account for the influence of the weekend (when there is a lower electricity demand and no hot water demand) on the system performance. Figs. 7-9 show the results from the $9^{\text {th }}$ to the $17^{\text {th }}$ of June.

It is observed that the electricity demand of the factory equipment matches the electricity generation during working hours, while the electricity required to cool the production room is constant throughout the day (light blue dashed line with plus signs in Fig. 7), and therefore at night, it cannot be instantaneously covered by the PVT collectors. Meanwhile, on sunny days, and especially on non-working days (see the last two days), there is a surplus of electricity (red line with crosses in Fig. 7) that is fed into the grid and can be imported later at night. As a consequence, as shown in Fig. 5, on an annual basis, 30.6\% of the electricity generated throughout the year is exported to the grid and imported when required, mainly to satisfy the electricity consumed to cool the production room.

Fig. 8 shows that around half of the hot water demand can be covered by the proposed S-CCHP system (45.4\% on an annual basis). Due to the low irradiance on the first weekend, the water tank temperature does not increase (red dotted line with triangles). Similarly, due to the lower 


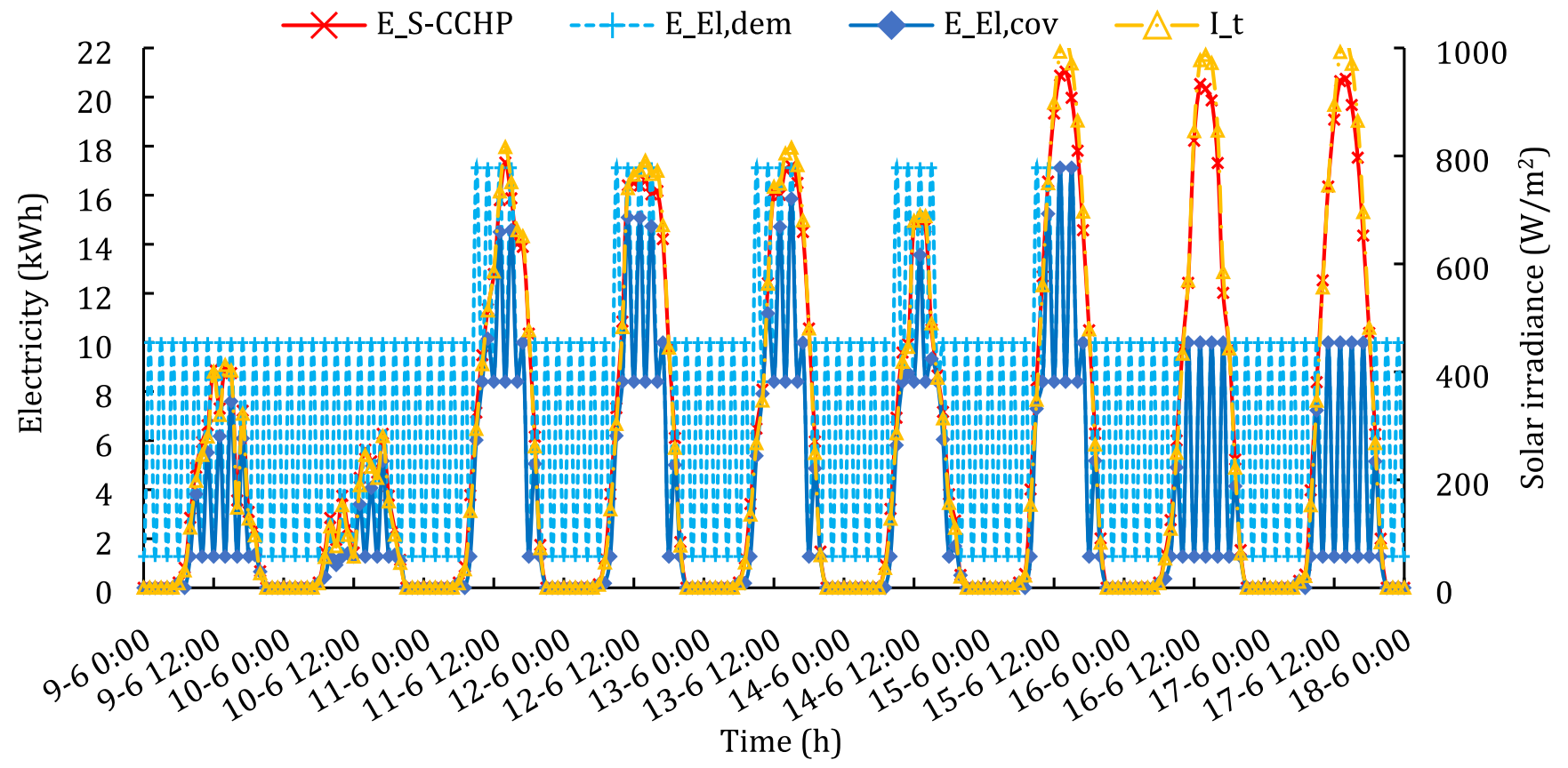

Fig. 7. Electricity generated ( $\left.E_{\mathrm{S}-\mathrm{S}-\mathrm{CCHP}}\right)$, electrical demand instantaneously covered $\left(E_{\mathrm{El}, \text { cov }}\right)$, total electricity demand $\left(E_{\mathrm{El}, \mathrm{dem}}\right)$, and total solar irradiance at tilted angle $\left(I_{t}\right)$ for the S-CCHP system based on covered PVT collectors and an AbCH during the period 9-17 June.

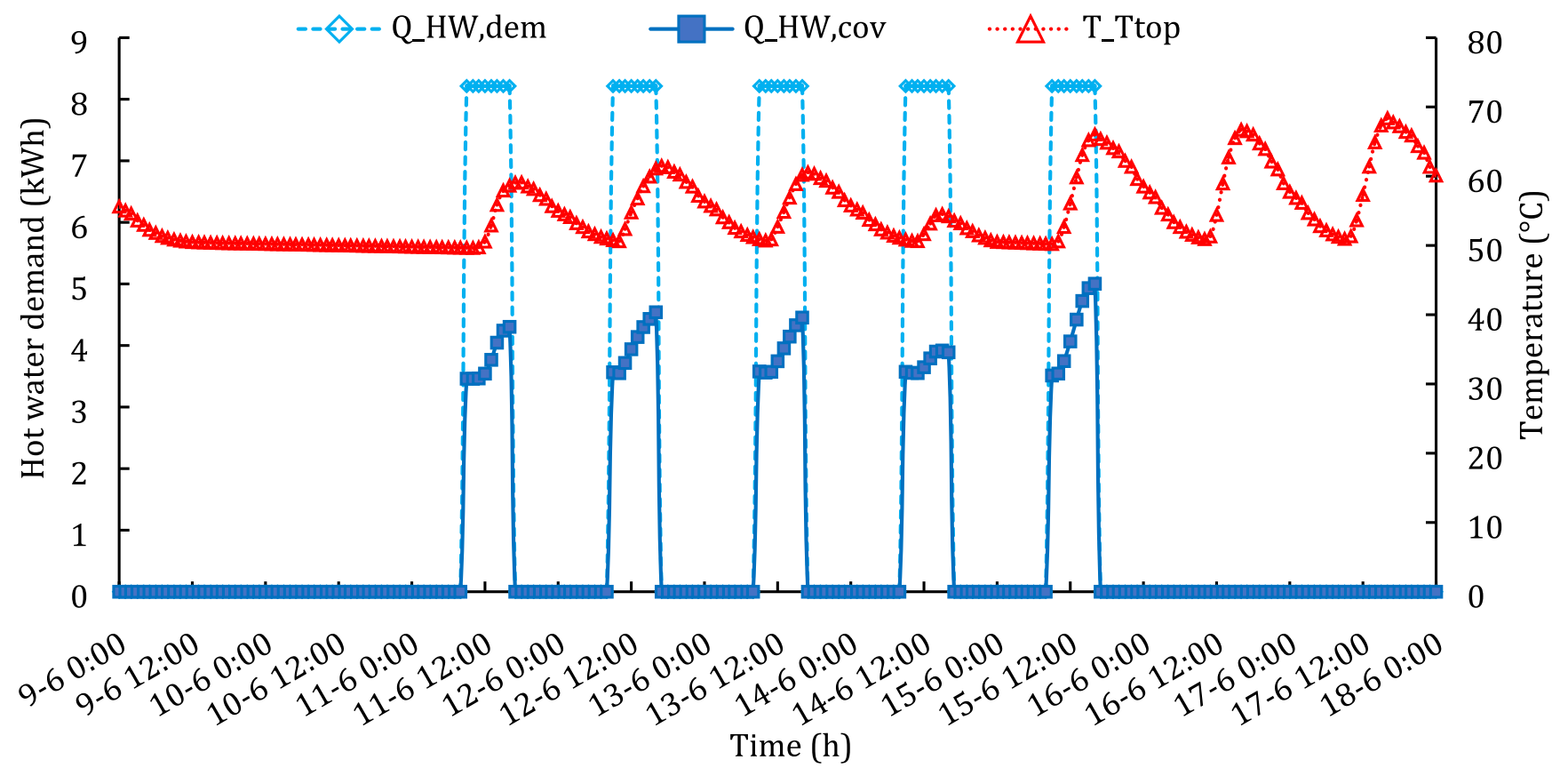

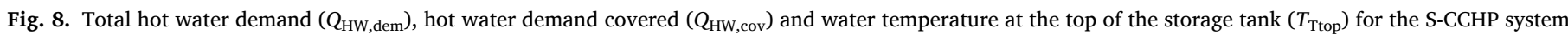
based on covered PVT collectors and an AbCH during the period 9-17 June.

solar irradiance on June $14^{\text {th }}$ compared to other days, the temperature at the top of the tank is lower, so less hot water demand is covered (dark blue line with squares). Instead, the tank temperature increases during the second weekend $\left(16^{\text {th }}-17^{\text {th }} \mathrm{June}\right)$, reaching around $70{ }^{\circ} \mathrm{C}$ at the top of the storage tank, as there are high irradiance levels while there is no hot water demand.

Fig. 9 depicts the thermal energy required by the AbCH to satisfy the cooling demand of the refrigeration chambers (light blue dashed lines with diamonds). The temperature reached at the top of the tank (red dotted lines with triangles) is not high enough to run the $\mathrm{AbCH}$, as its maximum is $70^{\circ} \mathrm{C}$, and therefore auxiliary heat is needed to increase the temperature of the water entering the $\mathrm{AbCH}$ to $80^{\circ} \mathrm{C}$ (orange line with plus signs), which is the temperature level required to start the unit. Therefore, only a limited amount of the cooling demand can be covered with the PVT thermal output (dark blue line with squares, $10.8 \%$ on an annual basis), while the rest is satisfied by the biomass boiler. Here it should be highlighted the importance of using a biomass boiler as auxiliary heater, as otherwise a considerably amount of light fuel oil would have to be burnt to cover the demand. In the last three days, the higher irradiance levels, and the fact that there is no hot water demand during the weekend (see Fig. 8), allows collecting more thermal energy from the PVT collectors, leading to an increase in the storage tank water 


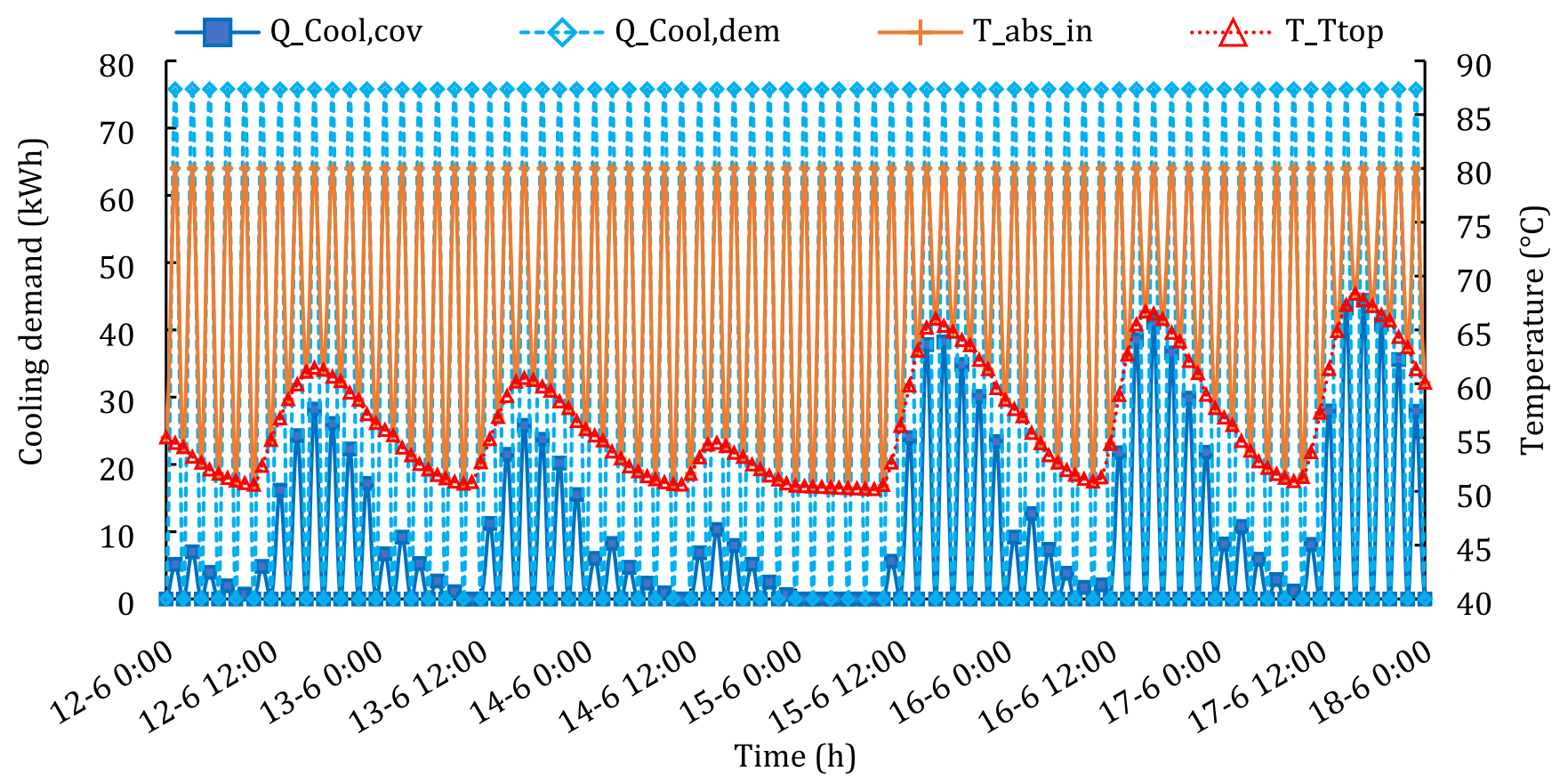

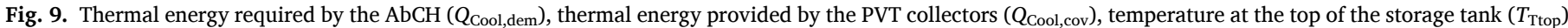

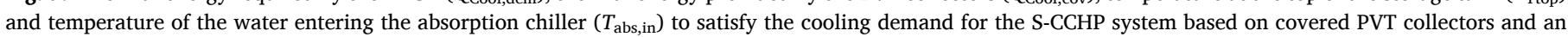
$\mathrm{AbCH}$ during the period 12-17 June.

temperature (red dotted lines with triangles) and thus a reduction in the auxiliary heat for the $\mathrm{AbCH}$ water.

These results reveal two main challenges in the energy provision for food-processing industries: the overlapping of the cooling and hot water demands, and the high hot water temperatures required $\left(80^{\circ} \mathrm{C}\right.$ to run the $\mathrm{AbCH}$ and up to $100^{\circ} \mathrm{C}$ for process hot water). This overlap limits the amount of solar thermal output provided to run the $\mathrm{AbCH}$, and the amount of process hot water that the thermal output of the PVT collectors can cover. These challenges could be overcome by i) uncoupling the cooling and hot water demands (e.g. shifting as far as possible the refrigeration cycle to times with no hot water demand); ii) satisfying the cooling demand with the current electrical chillers fed with the PVT electrical output (see Section 3.2.2); or iii) increasing the solar thermal output for example through the use of ETCs which reach higher hot water temperatures (see Section 3.2.3).

\subsubsection{Covered PVT collectors integrated with electrical chillers}

For comparison, transient results for the S-CCHP system based on covered PVT collectors and electrical chillers (the current units for the refrigeration chambers) are presented in Fig. 10. In this case, the system

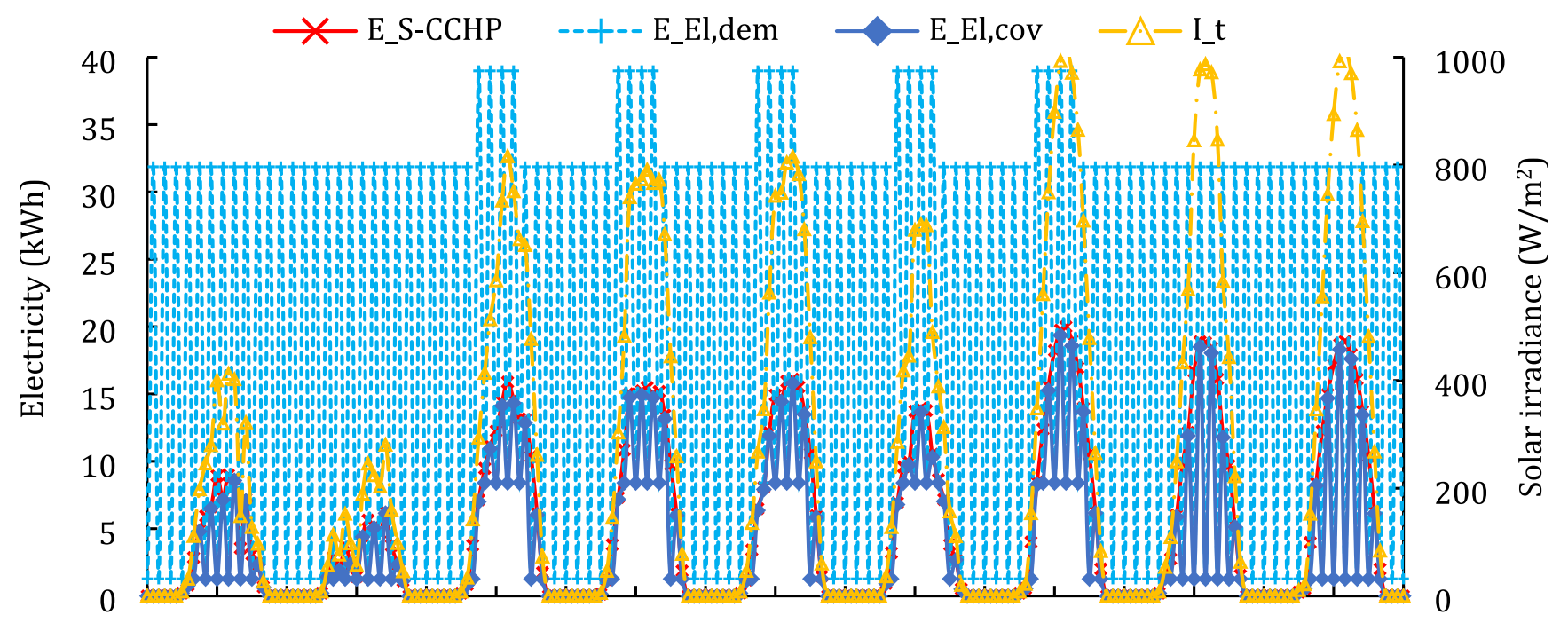

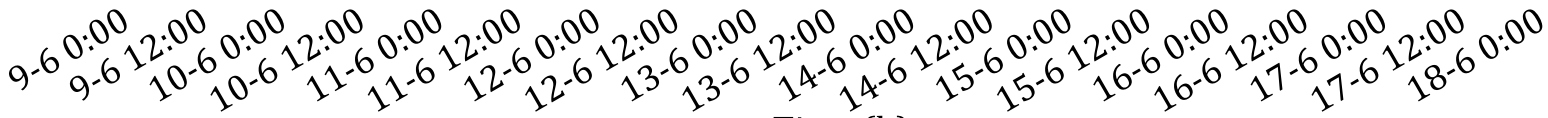

Time (h)

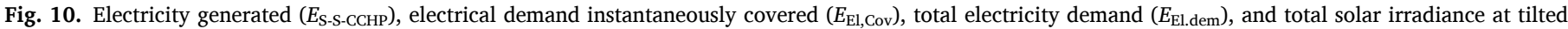
angle $\left(I_{t}\right)$ for the S-CCHP system based on covered PVT collectors and the current electrical chillers during the period 12-17 June. 
has the same electrical installed power $\left(31.8 \mathrm{~kW}_{\mathrm{p}}\right)$ and roof area covered by PVT collectors $\left(A_{\mathrm{cT}}=193 \mathrm{~m}^{2}\right)$ as the previous system. As before, a constant PVT collector flow-rate of $50 \mathrm{l} / \mathrm{h}$ is maintained [35], but in this case, the $V_{\mathrm{t}} / A_{\mathrm{cT}}$ ratio is $70 \mathrm{l} / \mathrm{m}^{2}$. This ratio is larger than in the previous case because the thermal energy demand is smaller (as there is no thermal demand for cooling), so a larger storage tank is required to store the thermal energy collected by the PVT collectors. The results presented are for the same days as the previous section, June $9^{\text {th }}-17^{\text {th }}$.

Fig. 10 shows that the total electricity consumption is significantly higher (light blue dashed lines with plus signs), due to the large electricity consumed to satisfy the total cooling demand $(134,000 \mathrm{kWh} /$ year as shown in Table 2). Consequently, only a limited amount of electricity can be instantaneously covered during the day (dark blue line with diamonds), particularly on sunny days. On an annual basis, only $17.3 \%$ of the total electricity consumption is instantaneously covered, while $25.6 \%$ of the electricity generated throughout the year is exported to the grid and imported back when required.

Similar results than the ones shown in Fig. 8 are obtained for the hot water demand, but in this case, as there is no thermal demand for cooling purposes, a larger percentage of the hot water demand can be met (66.2\% on an annual basis).

\subsubsection{Evacuated tube collectors integrated with an absorption chiller}

To increase the thermal output and hot water temperature of the solar system, the PVT collectors are replaced by ETCs. The same AbCH and biomass boiler (auxiliary heater) as before are considered. The system has nearly the same solar installed area as the previous systems $\left(A_{\mathrm{cT}}=194 \mathrm{~m}^{2}\right)$, which corresponds to 70 Thermomax DF400 collectors. In this case, the $V_{\mathrm{t}} / A_{\mathrm{cT}}$ ratio selected is $90 \mathrm{l} / \mathrm{m}^{2}$, since more storage capacity is required as the thermal output of the ETCs is considerably larger.

Fig. 11 shows that the temperature reached at the top of the storage tank is considerably higher than with the system based on covered PVT collectors (see Fig. 8), with temperatures of up to $90{ }^{\circ} \mathrm{C}$ or even slightly higher during the weekend when there is no hot water demand. Consequently, more hot water demand can be covered $(58.6 \%$ on an annual basis). The reason is the larger thermal efficiency of the ETCs compared to the efficiency of the PVT collectors (see eqs. (1, 2 and 6) in
Section 2), which leads to higher temperatures at the collector outlet as well as a larger amount of energy extracted from the collector (see "hot water generation" in Table 3), so that more energy can be transferred to the water storage tank.

A larger difference is observed in the cooling demand covered by the solar thermal output that feeds the $\mathrm{AbCH}$ (see Fig. 12). In this case, due to the higher temperature (up to temperatures of $90{ }^{\circ} \mathrm{C}$ or even slightly higher at the top of the storage tank) and the larger amount of hot water generated by the ETCs, due to the higher thermal efficiency of ETCs, a considerably larger percentage of the cooling demand of the refrigeration chambers can be met (dark blue line with squares). At some times, such as the early afternoons of the second weekend $\left(15^{\text {th }}-17^{\text {th }}\right.$ June) the temperature reached at the top of the tank is higher than the minimum temperature required to run the $\mathrm{AbCH}$, so the $\mathrm{AbCH}$ operates at a higher COP and most of the cooling demand can be covered with the solar thermal output. On an annual basis, $51.4 \%$ of the cooling demand of the refrigeration chambers can be met by the solar thermal output, which is almost 5 times higher than for the S-CCHP system with covered PVT collectors.

\subsection{Environmental and economic comparison of the different solar systems}

Table 3 summarises the main features, total investment cost, and annual results of the solar systems. The S-CCHP system based on uncovered PVT collectors and an AbCH has a shorter payback time (PBT) than the equivalent system with covered PVT collectors (28.6 vs. 30.7 years), even though only a negligible percentage of cooling demand satisfied by the $\mathrm{AbCH}$ is provided by the PVT thermal output, and the hot water demand covered by the solar system is also lower $(38.4 \% v s$. $45.4 \%$, see Fig. 13). This is due to the lower hot water temperature reached by the uncovered PVT collectors, because of the higher convective losses (see Eqs. (1-2) and Fig. 2). In turn, the lower temperatures reached by the uncovered PVT collectors result in higher electrical efficiency, and thus higher electricity generated (see Table 3). Therefore, the larger electricity demand covered (see Fig. 13), along with the lower investment cost, lead to the shorter $P B T$ of the uncovered PVT-based S-CCHP system.
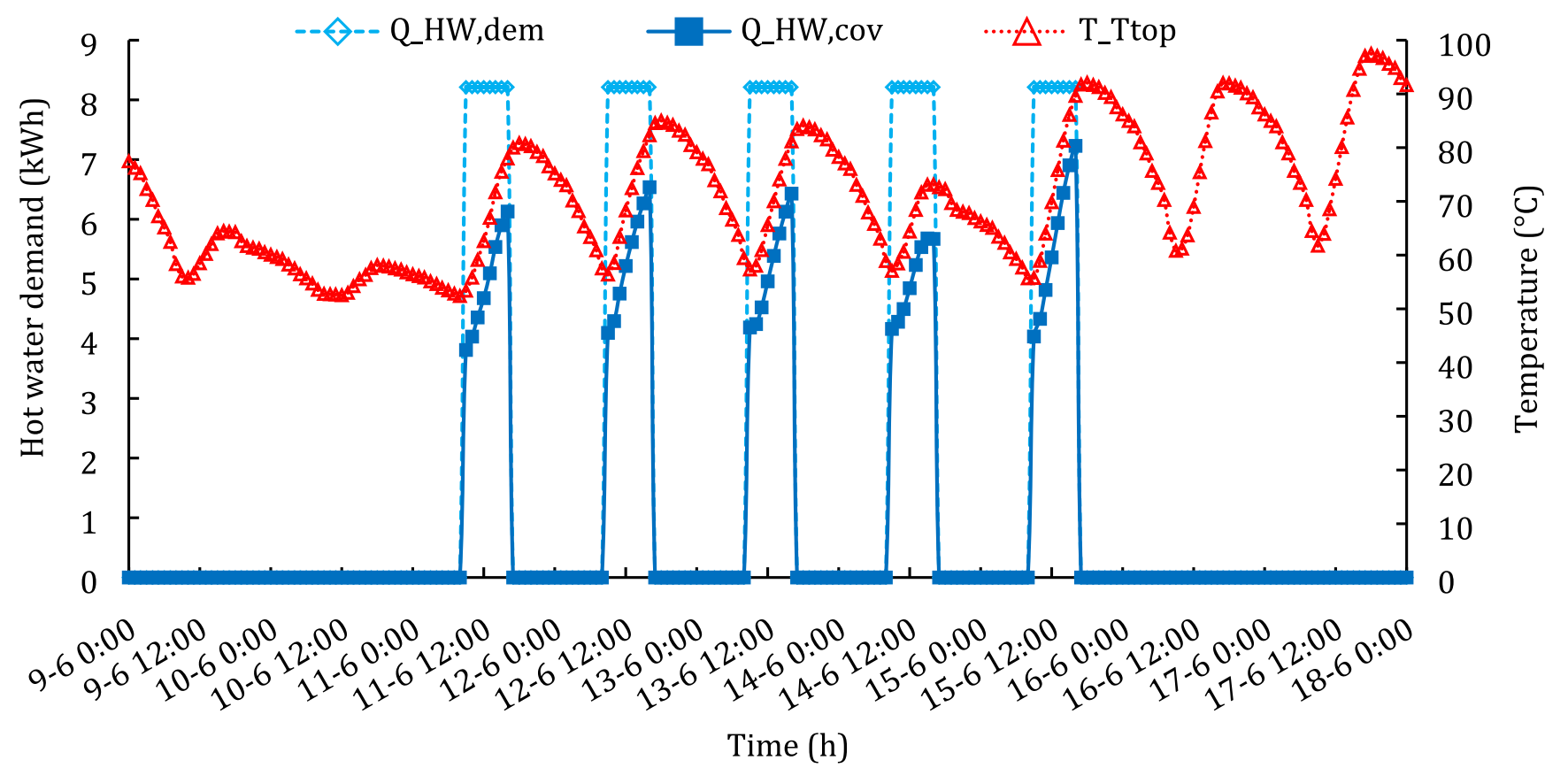

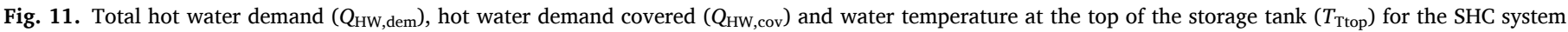
based on ETCs and an AbCH during the period 9-17 June. 
Table 3

System size, total investment cost, annual electrical and hot water generation, and main economic and environmental results of the proposed solar systems.

\begin{tabular}{|c|c|c|c|c|c|}
\hline & $\begin{array}{l}\text { Covered } \\
\mathrm{PVT}+ \\
\mathrm{AbCH}\end{array}$ & $\begin{array}{l}\text { Covered } \\
\text { PVT }+ \\
\text { electrical } \\
\text { chillers }\end{array}$ & $\begin{array}{l}\text { Uncovered } \\
\text { PVT }+ \\
\mathrm{AbCH}\end{array}$ & $\begin{array}{l}\text { Uncovered } \\
\text { PVT + } \\
\text { electrical } \\
\text { chillers }\end{array}$ & $\begin{array}{l}\mathrm{ETC}+ \\
\mathrm{AbCH}\end{array}$ \\
\hline $\begin{array}{l}\text { Number of } \\
\text { collectors } \\
(N)\end{array}$ & 120 & 120 & 105 & 105 & 70 \\
\hline $\begin{array}{l}\text { Installed } \\
\text { electrical } \\
\text { power } \\
\left(\mathrm{kW}_{\mathrm{p}}\right)\end{array}$ & 31.8 & 31.8 & 31.5 & 31.5 & - \\
\hline $\begin{array}{l}\text { Installed } \\
\text { area }\left(A_{\mathrm{cT}}\right. \\
\left.\mathrm{m}^{2}\right)\end{array}$ & 193 & 193 & 171 & 171 & 194 \\
\hline $\begin{array}{c}V_{\mathrm{t}} / A_{\mathrm{cT}} \text { ratio } \\
\left(1 / \mathrm{m}^{2}\right)\end{array}$ & 50 & 70 & 50 & 30 & 90 \\
\hline $\begin{array}{l}\text { Tank volume } \\
\left(\mathrm{m}^{3}\right)\end{array}$ & 9.7 & 13.5 & 8.5 & 5.1 & 12.6 \\
\hline $\begin{array}{l}\text { Investment } \\
\text { cost }\left(C_{0},\right. \\
\left.€ / \mathrm{m}^{2}\right)\end{array}$ & 751 & 576 & 696 & 461 & 602 \\
\hline $\begin{array}{l}\text { Electricity } \\
\text { generation } \\
\text { (MWh/ } \\
\text { year) }\end{array}$ & 40 & 38 & 42 & 41 & 0 \\
\hline $\begin{array}{l}\text { Hot water } \\
\text { generation } \\
\text { (MWh/ } \\
\text { year) }\end{array}$ & 41 & 12 & 14 & 6 & 159 \\
\hline $\begin{array}{l}\text { Net annual } \\
\text { savings } \\
\text { (AS, } \\
€ / \text { year) }\end{array}$ & 7114 & 6515 & 6059 & 6743 & 7868 \\
\hline $\begin{array}{l}\text { Payback } \\
\text { time (PBT, } \\
\text { years) }\end{array}$ & 30.7 & 23.4 & 28.6 & 14.3 & 18.3 \\
\hline $\begin{array}{c}\text { Annual } \mathrm{CO}_{2} \\
\text { emission } \\
\text { reduction } \\
\text { (ER, kg } \\
\mathrm{CO}_{2} \text { /year) }\end{array}$ & 48,719 & 19,239 & 49,313 & 20,265 & 37,221 \\
\hline
\end{tabular}

Retaining the current electrical chillers, rather than replacing them with an $\mathrm{AbCH}$, leads to considerably shorter payback times with both PVT collectors, which is mainly due to the lower investment cost. Furthermore, hot water and cooling demands do not compete for the same source, so a larger amount of hot water demand can be covered by the thermal output of the PVT collectors (see Fig. 13), while the cooling demand is satisfied by the PVT electricity generation. In this case, there is a considerable difference between the S-CCHP systems based on covered $v s$. uncovered PVT collectors. This is again due to the lower cost and the higher electricity generated of uncovered PVT collector, which in this case compensates for the lower thermal efficiency and thus hot water generation (see Table 3 and Fig. 13).

In terms of annual $\mathrm{CO}_{2}$ emission reduction, the systems based on PVT collectors and an $\mathrm{AbCH}$ have the potential to displace 2.5 times more annual $\mathrm{CO}_{2}$ emissions than the systems without the $\mathrm{AbCH}$. This reduction is mainly attributed to the biomass boiler that acts as an auxiliary heater, providing the balance of the heat required to supply all the hot water demand and the $\mathrm{AbCH}$.

The SHC system based on direct-flow ETCs and an $\mathrm{AbCH}$ has a lower investment cost and a considerably higher thermal output than the equivalent systems based on PVT collectors (see Table 3). Consequently, larger fractions of hot water and cooling demands are covered (see Fig. 13), which compensate for the lack of electricity generation, leading to larger net annual savings and thus shorter $P B T$ (18.3 years).

Fig. 14 shows the net present value (NPV), the environmental penalty cost savings (EPCS) and total cost savings (TCS) for two alternative carbon taxes, $0.023 € / \mathrm{kgCO}_{2}$ and $0.07 € / \mathrm{kgCO}_{2}$ [95] as explained in
Section 2.5. It is observed that the S-CCHP systems based on PVT collectors and an $\mathrm{AbCH}$ have negative NPVs, which means that the annual savings over the system lifetime do not cover its investment cost, so these systems are not economically attractive. However, when carbon pricing is considered (through the EPCS), these systems become an interesting alternative, particularly when the carbon tax is higher (see TCS columns in Fig. 14). The system with the highest NPV is the S-CCHP system based on uncovered PVT collectors and the current electrical chillers, as it is the system with the lowest investment cost. This system has also the highest TCS when $c_{\mathrm{CO} 2}=0.023 € / \mathrm{kgCO}_{2}$, while for higher carbon taxes the SHC system based on ETCs surpasses it, due to the larger annual $\mathrm{CO}_{2}$ emission reduction (see Table 3 ).

\subsection{Sensitivity analysis}

Finally, a sensitivity analysis is undertaken to estimate the influence of the S-CCHP system investment cost and the utility prices on the system cost-competitiveness. Considering the trends in the cost of PV panels, whose price decreased $65-75 \%$ in the period 2009-2013 [96], and the increase in the installed PVT collector area in recent years (which reached $1.1 \mathrm{Mm}^{2}$ at the end of 2018 [97]), it is expected that the PVT collector price will decrease in coming years.

If the price of the covered PVT collector is reduced by $50 \%$, the $P B T$ of the S-CCHP system based on covered PVT collectors and an $\mathrm{AbCH}$ would decrease from 30.7 years to 23.2 years, and thus the investment would be recovered before the end of the system lifetime ( 25 years); that is, its $N P V$ would become positive. If the collector price decreases by $70 \%$ and the system installation cost also decreases by $20 \%$ (which is feasible as more experience is gained), then the PBT would be 20 years. Still, the SHC system based on ETCs has a shorter PBT.

The S-CCHP system based on uncovered PVT collectors and the current electrical chillers shows more promising results, with a $P B T$ of 10.5 years if the collector price decreases by $50 \%$, and 9 years if it decreases by $70 \%$.

Apart from the high investment cost, another handicap that hinders the potential of the proposed S-CCHP systems is the significantly lower price of light fuel oil than the electricity price (about one half). If the light fuel oil price was the same as electricity price $\left(c_{\mathrm{lfo}}=c_{\mathrm{e}}=0.152\right.$ $€ / \mathrm{kWh}$ ), the $P B T$ of the S-CCHP system based on covered PVT collectors with an $\mathrm{AbCH}$ would decrease from 30.7 years to 23.1 years, while in the case of uncovered PVT collectors and electrical chillers the PBT would decrease from 14.3 years to 11.1 years.

\section{Conclusions}

This paper has presented an analysis of the feasibility of S-CCHP systems based on PVT collectors in the food-processing industry, specifically in a vegetable and fruit processing and canning plant. Despite this being a high energy-consuming sector with the bulk of demand occurring during the day, no similar research has been found in the literature; therefore this contribution constitutes the first step to overcome the barriers and expand the use of more efficient solar systems on promising applications. In summary, the research has found two main challenges: the overlapping of the cooling and hot water demands and the high hot water temperatures required. This makes the use of auxiliary heating essential for economic feasibility. Therefore, a biomass boiler is integrated within the S-CCHP for auxiliary heating, as it has a higher efficiency, lower fuel costs, and negligible associated $\mathrm{CO}_{2}$ emissions. The results show that this results in a considerably larger $\mathrm{CO}_{2}$ emission reduction, which further improves the environmental benefits of the proposed systems. These benefits are quantified through the total environmental penalty cost saving (EPCS) to better evaluate the overall potential of the proposed solutions.

The hourly energy demand profiles of the factory are estimated based on the data provided by the factory manager and used as inputs in the developed transient model. Transient simulations are run over a full year 


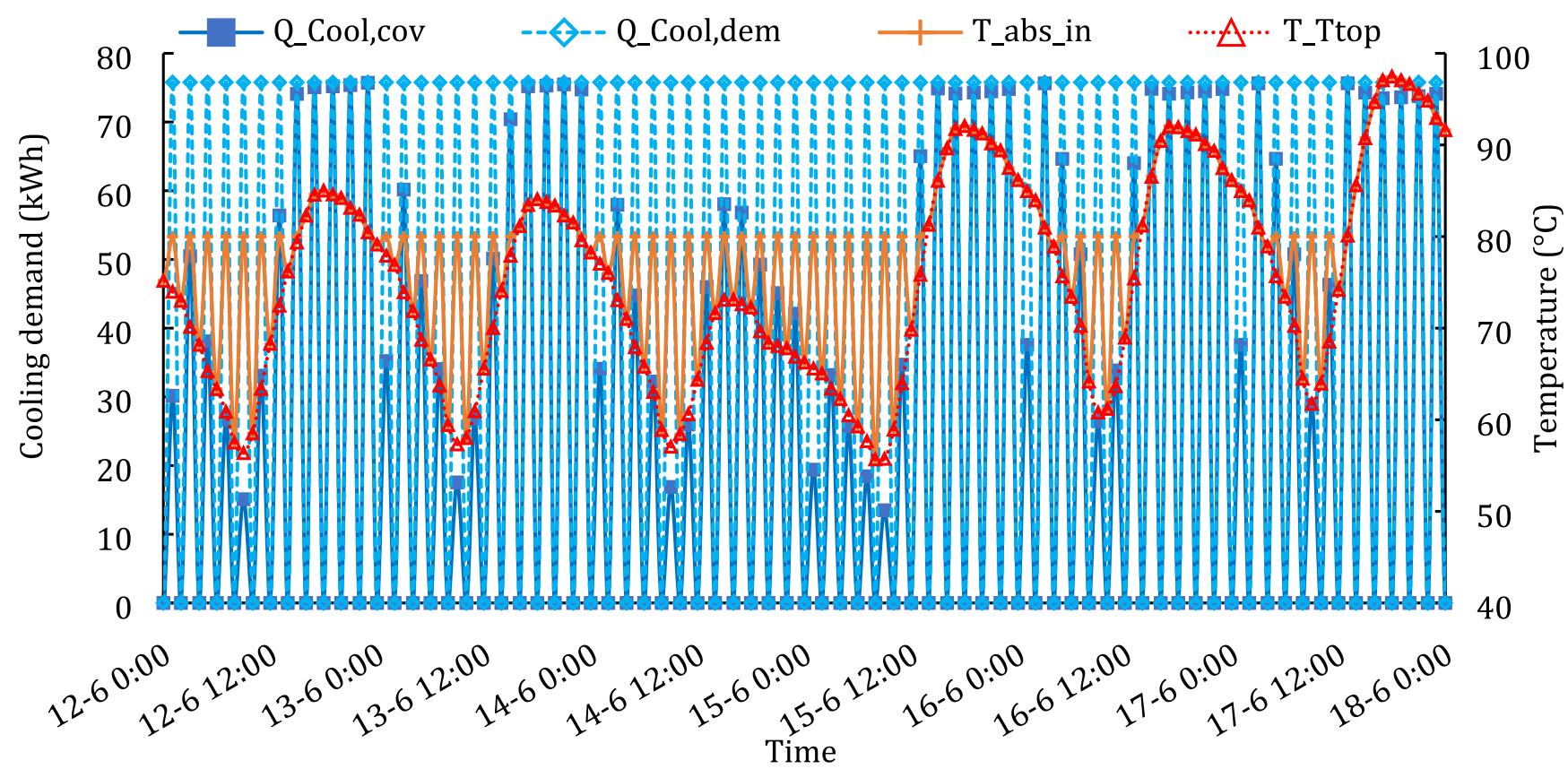

Fig. 12. Thermal energy required by the $\mathrm{AbCH}\left(Q_{\text {Cool,dem }}\right)$, thermal energy provided by the ETCs $\left(Q_{\text {Cool,cov }}\right)$, temperature at the top of the storage tank ( $\left.T_{\text {Ttop }}\right)$ and temperature of the water entering the absorption chiller $\left(T_{\mathrm{abs}, \text { in }}\right)$ to satisfy the cooling demand for the SHC system based on ETCs and an AbCH during the period 12-17 June.

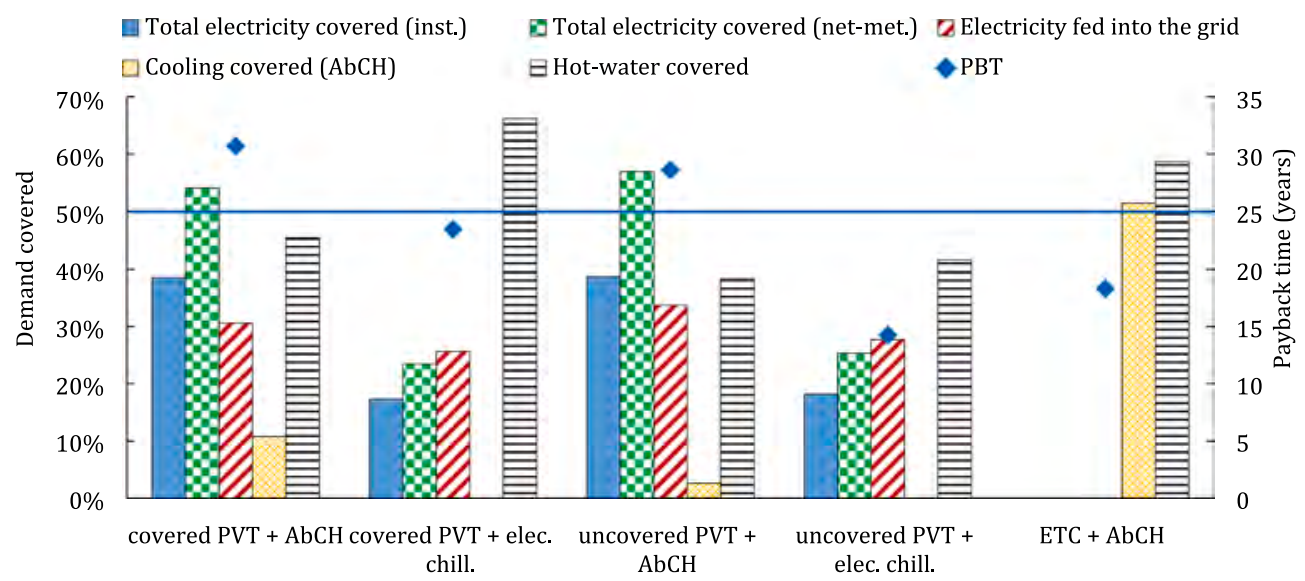

Fig. 13. Total electricity covered instantaneously and with net metering, electricity fed into the grid, hot water demand covered and cooling demand covered by the proposed solar systems, and corresponding payback times.

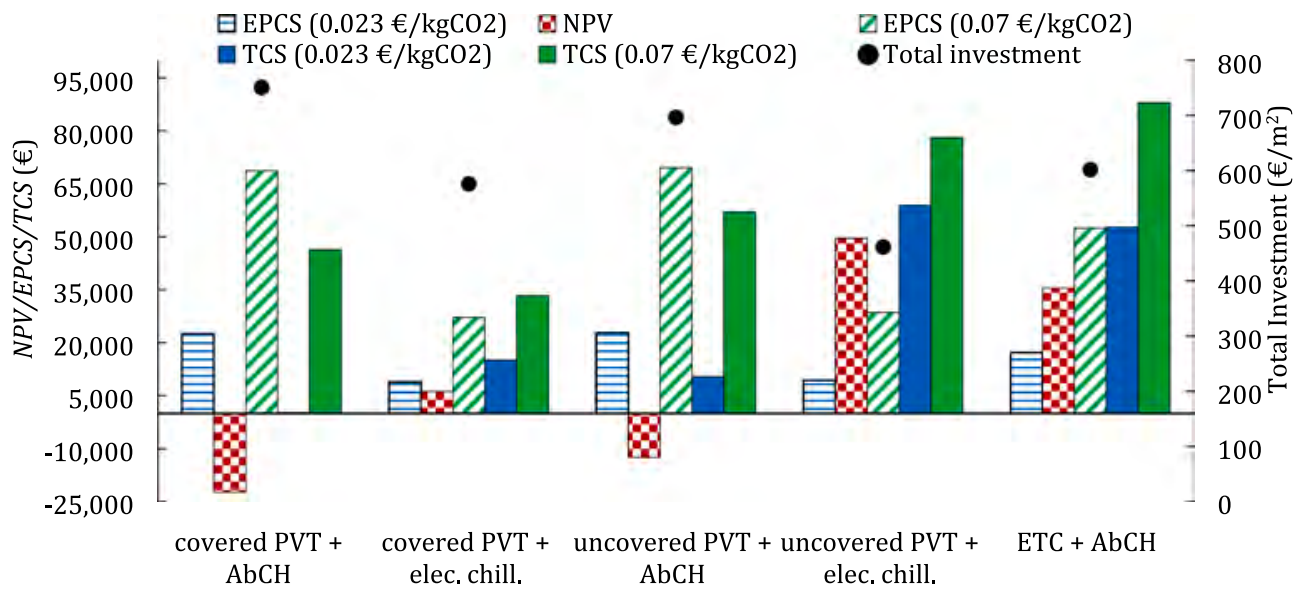

Fig. 14. Net present value (NPV), environmental penalty cost savings (EPCS), total cost savings (TCS) and total investment cost of the proposed solar systems. 
considering real weather data on an hourly basis, and the results are added up to obtain the annual energy savings which are used to estimate the system's economics and potential environmental benefits.

The analysis shows that there is an optimum number of PVT collectors $(N)$ that minimises the solar system payback time. In the S-CCHP system based on the covered PVT collectors and an AbCH, for $N<120$, the $P B T$ decreases exponentially with the system size, as more energy demand can be covered and therefore the annual savings increase. However, for larger $N$, the hot water demand covered and the amount of electricity demand instantaneously covered tend to an asymptote. Consequently, more electricity generated by the solar system is exported to the grid and imported later on. As the electricity price of the net metering option is one half of the electricity price, the economic savings decrease with the increase of electricity exported to the grid. Based on these results, the solar system size is set at $31.8 \mathrm{~kW}_{\mathrm{p}}$ electrical power $\left(A_{\mathrm{cT}}=193 \mathrm{~m}^{2}\right)$

Two main challenges are found for the S-CCHP system based on the covered PVT collectors, an AbCH and a biomass boiler: the overlapping of the cooling and hot water demands, and the high hot water temperatures required $\left(80^{\circ} \mathrm{C}\right.$ to run the $\mathrm{AbCH}$ and $100^{\circ} \mathrm{C}$ for process hot water) of the food-processing industry. This limits the amount of solar thermal output provided to run the $\mathrm{AbCH}$, and the amount of hot water demand that the thermal output of the PVT collectors can cover $(45.4 \%$ and $38.4 \%$ with the covered and uncovered PVT collectors respectively).

As an alternative system, the current electrical chillers are retained, rather than replacing them with an $\mathrm{AbCH}$, using directly the PVT electrical output. The results show that this option allows covering a larger fraction of the hot water demand, as in this case hot water and cooling demands do not compete for the same source, while decreasing the electricity exported and then imported later on, as part of the cooling demand is instantaneously satisfied by the PVT electricity generation. This, together with the lower investment cost (23\% and 34\% lower for the covered and uncovered PVT collectors respectively), lead to a shorter PBT than the equivalent system with the AbCH (28.6 years $v s$. 14.3 years with the uncovered PVT collectors).

In all the cases, the system based on uncovered PVT collectors appears to be economically more attractive than the system based on covered PVT collectors, mainly due to the lower investment cost and the higher electrical efficiency, which compensate for the lower thermal generation. This conclusion is highly influenced by the considerably lower price of fossil fuels compared to electricity (half the cost in this case study).

The SHC system based on ETCs integrated with the same AbCH and a biomass boiler has a shorter PBT than the PVT-based equivalent systems (18.3 years $v s$. 30.7 years in the case of covered PVT collectors). This is due to the lower investment cost (20\% lower than the S-CCHP system based on covered PVT collectors) and the significantly (almost 4 times) higher thermal generation of the ETCs compared to covered PVT collectors. Consequently, a larger amount of hot water demand (58.6\%) and a considerably (5 times) higher cooling demand (51.4\%) are covered with the solar thermal output, thus reducing the auxiliary heat needs and associated costs.

The results show that when the potential environmental benefit is quantified (in this case through carbon pricing), all the proposed solar systems become economically attractive, that is, all have positive total cost savings (TCS) at the end of the system lifetime (considering carbon taxes of $0.023 € / \mathrm{kgCO}_{2}$ or higher). This is partially attributed to the use of a biomass boiler as auxiliary heater instead of the current light fuel oil boiler, which has larger associated $\mathrm{CO}_{2}$ emissions. In the S-CCHP systems based on PVT collectors and an $\mathrm{AbCH}$, the high annual $\mathrm{CO}_{2}$ emission reduction (and thus high EPCS) compensates for the negative $N P V$. Still, the S-CCHP system based on uncovered PVT collectors and the current electrical chillers shows the most promising results (shortest $P B T$ and largest TCS), except for high carbon taxes (e.g. $0.07 € / \mathrm{kgCO}_{2}$ ), for which the SHC system based on ETCs surpasses it, due to the larger annual $\mathrm{CO}_{2}$ emission reduction.
It is concluded that one of the handicaps of the S-CCHP systems based on PVT collectors and an AbCH is the high investment cost of the system, mainly associated with the cost of the PVT collectors (around 40\%), along with the additional thermal equipment required (e.g. storage tank, $\mathrm{AbCH})$. Furthermore, the considerably lower price of fossil fuels compared to the electricity price (half of the price in this case study) means that systems that displace electricity are more attractive than those that displace fossil fuels.

\section{Declaration of Competing Interest}

The authors declare that they have no known competing financial interests or personal relationships that could have appeared to influence the work reported in this paper.

\section{Acknowledgements}

This work was undertaken in the framework of 3GSol, a project funded under the Retos-Colaboración 2017 Programme, National R\&D and Innovation Plan, by the Spanish Government, Ministry of Science, Innovation and Universities and co-funded by the EU, through the European Regional Development Fund (ERDF) [grant number RTC-20176026-3].

\section{Appendix A. Supplementary data}

Supplementary data to this article can be found online at https://doi. org/10.1016/j.applthermaleng.2020.116235.

\section{References}

[1] European Union, Energy in figures - Statistical pocketbook, 2018. doi:10.2 833/77817.

[2] European Commission, SET-Plan. ISSUES PAPER on strategic targets in the context of Action 5 - Develop new materials and technologies for energy efficiency solutions for buildings - Cross cutting heating and cooling technologies for buildings, 2016. <https://setis.ec.europa.eu> (accessed 28/11/2018).

[3] European Commission, An EU strategy on heating and cooling. Communication from the Commission to the European Parliament, the Council, the European Economic and Social Committee and the Committee of the Regions, 2016.

[4] Food for Life, Foodforlife - Home. <http://etp.fooddrinkeurope.eu> (accessed 21/ 4/2020).

[5] A. Buonomano, F. Calise, A. Palombo, Solar heating and cooling systems by absorption and adsorption chillers driven by stationary and concentrating photovoltaic/thermal solar collectors: modelling and simulation, Renew. Sustain. Energy Rev. 82 (2018) 1874-1908, https://doi.org/10.1016/j.rser.2017.10.059.

[6] K.R. Ullah, R. Saidur, H.W. Ping, R.K. Akikur, N. Shuvo, A review of solar thermal refrigeration and cooling methods, Renew. Sustain. Energy Rev. 51 (2013) 1428-1445, https://doi.org/10.1016/j.rser.2015.07.011.

[7] D.N. Nkwetta, J. Sandercock, A state-of-the-art review of solar air-conditioning systems, Renew. Sustain. Energy Rev. 60 (2016) 1351-1366, https://doi.org/ 10.1016/j.rser.2016.03.010.

[8] T. Otanicar, R.A. Taylor, P.E. Phelan, Prospects for solar cooling - an economic and environmental assessment, Sol. Energy. 86 (2012) 1287-1299, https://doi.org/ 10.1016/J.SOLENER.2012.01.020.

[9] D. Neyer, M. Ostheimer, N. Hauer, C. Halmdienst, W. Pink, Application of an adapted single-/half- effect NH3/H2O absorption chiller in tri-generation and solar cooling systems, Sol. Energy. 173 (2018) 715-727, https://doi.org/10.1016/J. SOLENER.2018.08.010.

[10] E. Bellos, C. Tzivanidis, Performance analysis and optimization of an absorption chiller driven by nanofluid based solar flat plate collector, J. Clean. Prod. 174 (2018) 256-272, https://doi.org/10.1016/J.JCLEPRO.2017.10.313.

[11] E. Bellos, C. Tzivanidis, K.A. Antonopoulos, Exergetic, energetic and financial evaluation of a solar driven absorption cooling system with various collector types, Appl. Therm. Eng. 102 (2016) 749-759, https://doi.org/10.1016/j. applthermaleng.2016.04.032.

[12] F. Calise, Thermoeconomic analysis and optimization of high efficiency solar heating and cooling systems for different Italian school buildings and climates, Energy Build. 42 (2010) 992-1003, https://doi.org/10.1016/j. enbuild.2010.01.011.

[13] F. Assilzadeh, S.A. Kalogirou, Y. Ali, K. Sopian, Simulation and optimization of a LiBr solar absorption cooling system with evacuated tube collectors, Renew. Energy 30 (2005) 1143-1159, https://doi.org/10.1016/J.RENENE.2004.09.017.

[14] A. Baghernejad, M. Yaghoubi, K. Jafarpur, Exergoeconomic optimization and environmental analysis of a novel solar-trigeneration system for heating, cooling and power production purpose, Sol. Energy 134 (2016) 165-179, https://doi.org/ 10.1016/J.SOLENER.2016.04.046. 
[15] M.J. Tierney, Options for solar-assisted refrigeration-trough collectors and double-effect chillers, Renew. Energy 32 (2007) 183-199, https://doi.org/ 10.1016/J.RENENE.2006.01.018.

[16] A. Shirazi, R.A. Taylor, S.D. White, G.L. Morrison, A systematic parametric study and feasibility assessment of solar-assisted single-effect, double-effect, and tripleeffect absorption chillers for heating and cooling applications, Energy Convers. Manag. 114 (2016) 258-277, https://doi.org/10.1016/j.enconman.2016.01.070.

[17] J. Muye, D.S. Ayou, R. Saravanan, A. Coronas, Performance study of a solar absorption power-cooling system, Appl. Therm. Eng. 97 (2016) 59-67, https://doi. org/10.1016/j.applthermaleng.2015.09.034.

[18] M. Alobaid, B. Hughes, J. Kaiser, D.O. Connor, A. Heyes, A review of solar driven absorption cooling with photovoltaic thermal systems, Renew. Sustain. Energy Rev. 76 (2017) 728-742, https://doi.org/10.1016/j.rser.2017.03.081.

[19] F.M. Montagnino, Solar cooling technologies. Design, application and performance of existing projects, Sol. Energy 154 (2017) 144-157, https://doi.org/10.1016/J SOLENER.2017.01.033.

[20] Y. Hang, M. Qu, R. Winston, L. Jiang, B. Widyolar, H. Poiry, Experimental based energy performance analysis and life cycle assessment for solar absorption cooling system at University of Californian, Merced, Energy Build. 82 (2014) 746-757, https://doi.org/10.1016/J.ENBUILD.2014.07.078.

[21] Z.Y. Xu, R.Z. Wang, Simulation of solar cooling system based on variable effect LiBr-water absorption chiller, Renew. Energy 113 (2017) 907-914, https://doi. org/10.1016/J.RENENE.2017.06.069.

[22] Z.S. Lu, R.Z. Wang, Z.Z. Xia, X.R. Lu, C.B. Yang, Y.C. Ma, G.B. Ma, Study of a nove solar adsorption cooling system and a solar absorption cooling system with new CPC collectors, Renew. Energy 50 (2013) 299-306, https://doi.org/10.1016/J. RENENE. 2012.07.001.

[23] P. Finocchiaro, M. Beccali, B. Nocke, Advanced solar assisted desiccant and evaporative cooling system equipped with wet heat exchangers, Sol. Energy 86 (2012) 608-618, https://doi.org/10.1016/J.SOLENER.2011.11.003.

[24] A. Lubis, J. Jeong, K. Saito, N. Giannetti, H. Yabase, M. Idrus Alhamid, Nasruddin, Solar-assisted single-double-effect absorption chiller for use in Asian tropical climates, Renew. Energy 99 (2016) 825-835, https://doi.org/10.1016/J. RENENE. 2016.07.055.

[25] A. Shirazi, R.A. Taylor, S.D. White, G.L. Morrison, Transient simulation and parametric study of solar-assisted heating and cooling absorption systems: an energetic, economic and environmental (3E) assessment, Renew. Energy 86 (2016) 955-971, https://doi.org/10.1016/J.RENENE.2015.09.014.

[26] K.F. Fong, C.K. Lee, T.T. Chow, Comparative study of solar cooling systems with building-integrated solar collectors for use in sub-tropical regions like Hong Kong, Appl. Energy 90 (2012) 189-195, https://doi.org/10.1016/J. APENERGY.2011.06.013.

[27] R. Thygesen, B. Karlsson, Simulation and analysis of a solar assisted heat pump system with two different storage types for high levels of PV electricity selfconsumption, Sol. Energy 103 (2014) 19-27, https://doi.org/10.1016/j. solener.2014.02.013.

[28] M. Herrando, A. Ramos, J. Freeman, I. Zabalza, C.N. Markides, Technoeconomic modelling and optimisation of solar combined heat and power systems based on flat-box PVT collectors for domestic applications, Energy Convers. Manag. 175 (2018) 67-85, https://doi.org/10.1016/j.enconman.2018.07.045.

[29] A. Herez, H. El Hage, T. Lemenand, M. Ramadan, M. Khaled, Review on photovoltaic/thermal hybrid solar collectors: classifications, applications and new systems, Sol. Energy 207 (2020) 1321-1347, https://doi.org/10.1016/j. solener.2020.07.062.

[30] M. Herrando, A. Ramos, I. Zabalza, C.N. Markides, A comprehensive assessment of alternative absorber-exchanger designs for hybrid PVT-water collectors, Appl. Energy 235 (2019) 1583-1602, https://doi.org/10.1016/J. APENERGY.2018.11.024.

[31] G. Colangelo, E. Favale, P. Miglietta, A. De Risi, Innovation in flat solar thermal collectors: a review of the last ten years experimental results, Renew. Sustain. Energy Rev. 57 (2016) 1141-1159, https://doi.org/10.1016/j.rser.2015.12.142.

[32] G. Colangelo, D. Romano, T. Giuseppe Marco, Performance evaluation of a new type of combined photovoltaic-thermal solar collector, J. Sol. Energy Eng. 137 (2015) 12, https://doi.org/10.1115/1.4030727.

[33] M. Herrando, C.N. Markides, Hybrid PV and solar-thermal systems for domestic heat and power provision in the UK: techno-economic considerations, Appl. Energy. 161 (2016) 512-532, https://doi.org/10.1016/j.apenergy.2015.09.025.

[34] IEA, Task 60: PVT Systems: Application of PVT Collectors and New Solutions in HVAC Systems. <http://task60.iea-shc.org > (accessed 3/8/2020).

[35] M. Herrando, A.M. Pantaleo, K. Wang, C.N. Markides, Solar combined cooling, heating and power systems based on hybrid PVT, PV or solar-thermal collectors for building applications, Renew. Energy 143 (2019) 637-647, https://doi.org/ 10.1016/j.renene.2019.05.004.

[36] M. Herrando, A. Ramos, I. Zabalza, C.N. Markides, Energy Performance of a Solar Trigeneration System Based on a Novel Hybrid PVT Panel for Residential Applications. ISES Solar World Congress 2017 - IEA SHC International Conference on Solar Heating and Cooling for Buildings and Industry 2017, Proceedings, Abu Dhabi (UAE), 2017, p. 1090-101.

[37] J. Ji, L. Keliang, T.T. Chow, G. Pei, H. Wei, H. Hanfeng, Performance analysis of a photovoltaic heat pump, Appl. Energy. 85 (2008) 680-693, https://doi.org/ 10.1016/j.apenergy.2008.01.003.

[38] G. Xu, S. Deng, X. Zhang, L. Yang, Y. Zhang, Simulation of a photovoltaic/therma heat pump system having a modified collector/evaporator, Sol. Energy 83 (2009) 1967-1976, https://doi.org/10.1016/j.solener.2009.07.008.
[39] H.-L. Tsai, Modeling and validation of refrigerant-based PVT-assisted heat pump water heating (PVTA-HPWH) system, Sol. Energy 122 (2015) 36-47, https://doi. org/10.1016/J.SOLENER.2015.08.024.

[40] C. Zhou, R. Liang, A. Riaz, J. Zhang, J. Chen, Experimental investigation on the trigeneration performance of roll-bond photovoltaic thermal heat pump system during summer, Energy Convers. Manag. 184 (2019) 91-106, https://doi.org/ 10.1016/j.enconman.2018.12.028.

[41] A. Buonomano, F. Calise, A. Palombo, Solar heating and cooling systems by CPVT and ET solar collectors: a novel transient simulation model, Appl. Energy 103 (2013) 588-606, https://doi.org/10.1016/J.APENERGY.2012.10.023.

[42] F. Calise, M. Dentice d'Accadia, A. Palombo, L. Vanoli, Dynamic simulation of a novel high-temperature solar trigeneration system based on concentrating photovoltaic/thermal collectors, Energy 61 (2013) 72-86, https://doi.org/ 10.1016/J.ENERGY.2012.10.008.

[43] S. Sanaye, A. Sarrafi, Optimization of combined cooling, heating and power generation by a solar system, Renew. Energy 80 (2015) 699-712, https://doi.org/ 10.1016/J.RENENE. 2015.02.043.

[44] U. Eicker, A. Dalibard, Photovoltaic-thermal collectors for night radiative cooling of buildings, Sol. Energy 85 (2011) 1322-1335, https://doi.org/10.1016/j. solener.2011.03.015.

[45] R.S. Kamel, A.S. Fung, Modeling, simulation and feasibility analysis of residential BIPV/T+ASHP system in cold climate-Canada, Energy Build. 82 (2014) 758-770, https://doi.org/10.1016/j.enbuild.2014.07.081.

[46] F. Calise, M. Dentice d'Accadia, R.D. Figaj, L. Vanoli, A novel solar-assisted heat pump driven by photovoltaic/thermal collectors: dynamic simulation and thermoeconomic optimization, Energy 95 (2016) 346-366, https://doi.org/ 10.1016/J.ENERGY.2015.11.071.

[47] F. Calise, R.D. Figaj, L. Vanoli, A novel polygeneration system integrating photovoltaic/thermal collectors, solar assisted heat pump, adsorption chiller and electrical energy storage: dynamic and energy-economic analysis, Energy Convers. Manag. 149 (2017) 798-814, https://doi.org/10.1016/J ENCONMAN.2017.03.027.

[48] E. Bellos, C. Tzivanidis, K. Moschos, K.A. Antonopoulos, Energetic and financia evaluation of solar assisted heat pump space heating systems, Energy Convers. Manag. 120 (2016) 306-319, https://doi.org/10.1016/J ENCONMAN.2016.05.004

[49] G. Wang, Y. Zhao, Z. Quan, J. Tong, Application of a multi-function solar-heat pump system in residential buildings, Appl. Therm. Eng. 130 (2018) 922-937, https://doi.org/10.1016/j.applthermaleng.2017.10.046.

[50] R.S. Kamel, A.S. Fung, P.R.H. Dash, Solar systems and their integration with heat pumps: a review, Energy Build. 87 (2015) 395-412, https://doi.org/10.1016/j. enbuild.2014.11.030.

[51] J. Cai, J. Ji, Y. Wang, F. Zhou, B. Yu, A novel PV/T-air dual source heat pump water heater system: dynamic simulation and performance characterization, Energy Convers. Manag. 148 (2017) 635-645, https://doi.org/10.1016/J. ENCONMAN.2017.06.036

[52] A. Buonomano, F. Calise, A. Palombo, M. Vicidomini, Adsorption chiller operation by recovering low-temperature heat from building integrated photovoltaic thermal collectors: modelling and simulation, Energy Convers. Manag. 149 (2017) 1019-1036, https://doi.org/10.1016/j.enconman.2017.05.005.

[53] E.G. Papoutsis, I.P. Koronaki, V.D. Papaefthimiou, Numerical simulation and parametric study of different types of solar cooling systems under Mediterranean climatic conditions, Energy Build. 138 (2017) 601-611, https://doi.org/10.1016/ J.ENBUILD. 2016.12.094.

[54] F. Calise, M. Dentice D'Accadia, L. Vanoli, Design and dynamic simulation of a novel solar trigeneration system based on hybrid photovoltaic/thermal collectors (PVT), Energy Convers. Manag. 60 (2012) 214-225, https://doi.org/10.1016/j. enconman.2012.01.025.

[55] A. del Amo, Solar trigeneration: a transitory simulation of HVAC systems using different typologies of hybrid panels, J. Sustain. Dev. Energy, Water Environ. Syst. 2 (2014) 1-14, https://doi.org/10.13044/j.sdewes.2014.02.0001.

[56] F. Calise, M. Dentice d'Accadia, R.D. Figaj, L. Vanoli, Thermoeconomic optimization of a solar-assisted heat pump based on transient simulations and computer Design of Experiments, Energy Convers. Manag. 125 (2016) 166-184, https://doi.org/10.1016/J.ENCONMAN.2016.03.063.

[57] N. Hartmann, C. Glueck, F.P. Schmidt, Solar cooling for small office buildings: comparison of solar thermal and photovoltaic options for two different European climates, Renew. Energy 36 (2011) 1329-1338, https://doi.org/10.1016/J، RENENE.2010.11.006.

[58] H. Yousefi, M.H. Ghodusinejad, A. Kasaeian, Multi-objective optimal component sizing of a hybrid ICE + PV/T driven CCHP microgrid, Appl. Therm. Eng. 122 (2017) 126-138, https://doi.org/10.1016/J.APPLTHERMALENG. 2017.05.017.

[59] H. Chen, Z. Li, Y. Xu, Evaluation and comparison of solar trigeneration systems based on photovoltaic thermal collectors for subtropical climates, Energy Convers. Manag. 199 (2019) 111959, https://doi.org/10.1016/j.enconman.2019.111959.

[60] A. Tiwari, M.S. Sodha, Performance evaluation of hybrid PV/thermal water/air heating system: a parametric study, Renew. Energy 31 (2006) 2460-2474, https:// doi.org/10.1016/j.renene.2005.12.002.

[61] H.A. Zondag, D.W. de Vries, W.G.J. van Helden, R.J.C. van Zolingen, A.A. van Steenhoven, The yield of different combined PV-thermal collector designs, Sol Energy 74 (2003) 253-269, https://doi.org/10.1016/S0038-092X(03)00121-X.

[62] V.N. Drosou, P.D. Tsekouras, T.I. Oikonomou, P.I. Kosmopoulos, C.S. Karytsas, The HIGH-COMBI project: high solar fraction heating and cooling systems with combination of innovative components and methods, Renew. Sustain. Energy Rev. 29 (2014) 463-472, https://doi.org/10.1016/j.rser.2013.08.019. 
[63] U. Eicker, A. Colmenar-Santos, L. Teran, M. Cotrado, D. Borge-Diez, Economic evaluation of solar thermal and photovoltaic cooling systems through simulation in different climatic conditions: an analysis in three different cities in Europe, Energy Build. 70 (2014) 207-223, https://doi.org/10.1016/J.ENBUILD.2013.11.061.

[64] L. Croci, L. Molinaroli, P. Quaglia, Dual source solar assisted heat pump model development, validation and comparison to conventional systems, Energy Procedia 140 (2017) 408-422, https://doi.org/10.1016/J.EGYPRO.2017.11.153.

[65] G. Mittelman, A. Kribus, A. Dayan, Solar cooling with concentrating photovoltaic/ thermal (CPVT) systems, Energy Convers. Manag. 48 (2007) 2481-2490, https:// doi.org/10.1016/J.ENCONMAN.2007.04.004.

[66] J. Guo, S. Lin, J.I. Bilbao, S.D. White, A.B. Sproul, A review of photovoltaic thermal (PV/T) heat utilisation with low temperature desiccant cooling and dehumidification, Renew. Sustain. Energy Rev. 67 (2017) 1-14, https://doi.org/ 10.1016/J.RSER.2016.08.056.

[67] M. Beccali, P. Finocchiaro, B. Nocke, Energy and economic assessment of desiccant cooling systems coupled with single glazed air and hybrid PV/thermal solar collectors for applications in hot and humid climate, Sol. Energy 83 (2009) 1828-1846, https://doi.org/10.1016/j.solener.2009.06.015.

[68] K. Wang, M. Herrando, A.M. Pantaleo, C.N. Markides, Technoeconomic assessments of hybrid photovoltaic-thermal vs. conventional solar-energy systems: case studies in heat and power provision to sports centres, Appl. Energy. 254 (2019) 113657, https://doi.org/10.1016/J.APENERGY.2019.113657.

[69] M. Herrando, A. Ramos, I. Zabalza, Cost competitiveness of a novel PVT-based solar combined heating and power system: Influence of economic parameters and financial incentives, Energy Convers. Manag. 166 (2018) 758-770, https://doi. org/10.1016/j.enconman.2018.04.005.

[70] T. Matuska, Performance and economic analysis of hybrid PVT collectors in solar DHW system, Energy Procedia 48 (2014) 150-156, https://doi.org/10.1016/j. egypro.2014.02.019.

[71] P.J. Axaopoulos, E.D. Fylladitakis, Performance and economic evaluation of a hybrid photovoltaic/thermal solar system for residential applications, Energy Build. 65 (2013) 488-496, https://doi.org/10.1016/j.enbuild.2013.06.027.

[72] K.-K. Tse, T.-T. Chow, Y. Su, Performance evaluation and economic analysis of a full scale water-based photovoltaic/thermal (PV/T) system in an office building, Energy Build. 122 (2016) 42-52, https://doi.org/10.1016/j.enbuild.2016.04.014.

[73] M. Herrando, C.N. Markides, K. Hellgardt, A UK-based assessment of hybrid PV and solar-thermal systems for domestic heating and power: system performance, Appl. Energy 122 (2014) 288-309, https://doi.org/10.1016/j.apenergy.2014.01.061.

[74] A. Ramos, I. Guarracino, A. Mellor, D. Alonso-álvarez, P. Childs, N.J. Ekins-daukes, C.N. Markides, Solar-Thermal and Hybrid Photovoltaic-Thermal Systems for Renewable Heating, Grantham Institute, Brief. Pap. No 22. (2017) Imperial College London.

[75] A.H.A. Al-Waeli, H.A. Kazem, M.T. Chaichan, K. Sopian, Photovoltaic/Thermal (PV/T) Systems, 2019. doi:10.1007/978-3-030-27824-3.

[76] D. Diakosavvas, Improving Energy Efficiency in the Agro-Food Chain, France, Paris, 2017.
[77] S.A. Klein, TRNSYS 18: A Transient System Simulation Program.

[78] Meteonorm Data Base, Meteonorm Data Base, 2017.

[79] Y. Liu, E.A. Groll, K. Yazawa, O. Kurtulus, Energy-saving performance and economics of $\mathrm{CO} 2$ and $\mathrm{NH} 3$ heat pumps with simultaneous cooling and heating applications in food processing: case studies, Int. J. Refrig. 73 (2017) 111-124, https://doi.org/10.1016/J.IJREFRIG.2016.09.014.

[80] SOGECAL, NCK 2-FLUE FIRETUBE BOILER - SOGECAL'S COMPACT SERIES, (n. d.). <https://www.sogecal.com/en/nck-2-flue-firetube-boiler-sogecals-compact-se ries $>$ (accessed 26/4/2019).

[81] EndeF, Endef - Energy, Development and Future < endef.com $>$ (accessed 10/8/ 2020).

[82] Lapesa, GEISER INOX | lapesa, 2017. http://www.lapesa.es/en/domestic-hot-wate r/geiser-inox (accessed 19/7/2017).

[83] AGO AG, AGO AG Energie + Anlagen · Home, <https://www.ago.ag/home.html> (accessed 26/4/2019).

[84] Termosun, Biomass boiler HERZ, https://www.termosun.com/termosun-calderas/ gama-herz (accessed 12/2/2020).

[85] Kingspan, Thermomax DF400 Evacuated Tube Collectors, <https://www.kings pan.com/gb/en-gb/products/renewable-technologies/solar-thermal/solar-evac uated-tube-collectors/thermomax-df400-evacuated-tube-br-collectors $>$ (accessed 19/11/2018).

[86] Barilla Solar, Wholesale Solar Thermal Supplies Barilla Solar. <http://www. barillasolar.co.uk> (accessed 19/7/2017).

[87] Viridian Solar, The Pod - Solar Water Heating Simplified. <http://www.viridianso lar.co.uk/solar-products-solar-heating-with-combi-pod.html> (accessed 19/7/ 2017).

[88] Wagner Renewable, Home Page - Wagner Renewables Ltd. <http://www.wa gnersolarshop.com> (accessed 19/7/2017).

[89] S.A. Kalogirou, Solar energy engineering: processes and systems, second ed., Academic Press, 2014. doi:10.1016/B978-0-12-374501-9.00014-5.

[90] Y. Kim, K. Thu, H. Kaur, C. Singh, K. Choon, Thermal analysis and performance optimization of a solar hot water plant with economic evaluation, Sol. Energy 86 (2012) 1378-1395, https://doi.org/10.1016/j.solener.2012.01.030.

[91] International Energy Agency (IEA), Projected Costs of Generating Electricity, 2010.

[92] fixr, Operation and Maintenance costs of boilers, https://www.fixr.es/guias-de-p recios/revision-caldera (accessed 13/2/2020)

[93] S.A. Kalogirou, Y. Tripanagnostopoulos, Hybrid PV/T solar systems for domestic hot water and electricity production, Energy Convers. Manag. 47 (2006) 3368-3382, https://doi.org/10.1016/j.enconman.2006.01.012.

[94] Gobierno de España, Factores de emisión de CO2 y coeficientes de paso a energía primaria de diferentes fuentes de energía final consumidas en el sector de edificios en España, 2016.

[95] World Bank Group, State and Trends of Carbon Pricing 2018, Washington DC, 2018.

[96] IRENA, Renewable Power Generation Costs in 2014, 2015.

[97] T. Ramschak, Subtask A PVT-systems in operation. IEA Task 60, 2019. 